\title{
LONG-TERM MONITORING OF THE THREATENED LESSER GUINEAFLOWER HIBBERTIA CALYCINA (DC.) N.A.WAKEF. (DILLENIACEAE) IN TASMANIA
}

\author{
by Perpetua A.M. Turner, Mark Wapstra, Allison Woolley, Katriona Hopkins, Amelia J. Koch \\ and Fred Duncan
}

(with four text-figures, two plates, one table and five appendices)

\begin{abstract}
Turner, P.A.M., Wapstra, M., Woolley, A., Hopkins, K., Koch, A.J. \& Duncan, F. 2020 (9:xii): Long-term monitoring of the threatened lesser guineaflower Hibbertia calycina (DC.) N.A.Wakef. (Dilleniaceae) in Tasmania. Papers and Proceedings of the Royal Society of Tasmania 154: 61-82. https://doi.org/10.26749/rstpp.154.61 ISSN: 0080-4703. Forest Practices Authority, 30 Patrick Street, Hobart, Tasmania 7001, Australia (PAMT*, AJK); Discipline of Biological Sciences, School of Natural Sciences, University of Tasmania, Hobart, Tasmania 7001, Australia (PAMT*, AJK); Environmental Consulting Options Tasmania, 28 Suncrest Avenue, Lenah Valley, Tasmania 7008, Australia (MW); Department of Primary Industries, Parks, Water and Environment, 134 Macquarie Street, Hobart, Tasmania 7000, Australia (AW); Stonyford, St Helens, Tasmania 7216, Australia (KH); The Plant Press, 386 Richmond Road, Cambridge, Tasmania 7170, Australia (FD). *Author for correspondence. Email: perpetua.turner@utas.edu.au

This paper describes the distribution of the threatened shrub Hibbertia calycina (DC.) N.A. Wakef., a distinctive plant restricted to northeast Tasmania. It compares changes over time in population size and evaluates the species response to disturbance. Results found H. calycina distribution is restricted to isolated clumps on highly insolated ridges and steep upper slopes of fine-grained Mathinna-series sedimentary rocks in dry sclerophyll forest dominated by Eucalyptus sieberi L.Johnson. Nine populations were documented with an estimated area of occupancy of $0.43 \mathrm{~km}^{2}$ and area of extent measuring $95 \mathrm{~km}^{2}$, demonstrating that the current listing of $H$. calycina as vulnerable is appropriate on Tasmania's Threatened Species Protection Act 1995. We believe that the distribution of the present population is a result of natural factors (i.e., restricted habitat range and natural fire events) and anthropogenic factors (managed fire regime and illegal firewood cutting). Although frequent fire and roading have the potential to impact populations, $H$. calycina appears to be stable without active management in a landscape of patchy, regular, low severity fire. Our results indicate susceptibility to the soil-borne pathogen Phytophthora cinnamomi is likely less problematic than previously postulated, yet more data and research is required before management is changed.
\end{abstract}

Key Words: fire, forest, Phytophthora, management, population, conservation, plantation.

\section{INTRODUCTION}

Hibbertia calycina (DC.) N.A.Wakef. (de Salas \& Baker 2019) is a non-endemic native vascular plant species listed as vulnerable on the schedules of Tasmania's Threatened Species Protection Act 1995 but not listed at a national level. H. calycina is managed according to the Threatened Species Strategy for Tasmania (DPIPWE 2000), which addresses key threatening processes affecting species identified as having a high priority for conservation (DPIPWE 2000, Commonwealth of Australia 2015). Also found in Victoria, New South Wales and the Australian Capital Territory, the original Tasmanian threatened species listing of $H$. calycina is due to herbarium and early observational data citing a restricted range and localised distribution with little else published on the taxon's response to disturbance. Many of Australia's vascular plants are declared as threatened with extinction (DEE 2020) due to their localised distributions and restricted ranges which make them particularly vulnerable to habitat loss, disease, invasive species and altered disturbance regimes (Dirzo \& Raven 2003, Burgman et al. 2007, Silcock \& Fensham 2018). It is widely recognised that ongoing research and monitoring of changes and trends in the distribution, abundance and response of species to disturbance is important for providing scientific credibility to conserving threatened species (Craigie et al. 2018, Legge et al. 2018).

H. calycina has an erect habit and can reach heights of up to $1.4 \mathrm{~m}$. Showy yellow flowers of approx. $15 \mathrm{~mm}$ diameter are often observed in spring, with a secondary flowering in autumn (Harden \& Everett 1990, Toelken 1996, authors pers. obs.) and can occur on very small plants. Despite being distinctive and its area having a strong European history of mining dating back to the 1880s (Bacon 2013), $H$. calycina was not recorded until 1980. Records from 1980-1995 reported five distinct populations with this time period also seeing the discovery of other species: e.g., Mirbelia oxylobioides F.Muell from Heathy Hills Reserve in southern Tasmania (Threatened Species Section 2020). It is likely that in Tasmania $H$. calycina was overlooked and we do not believe it was introduced (appendix 1).

The distribution of $H$. calycina coincided with commercial timber harvesting in the 1990s and little was known about the potential impacts to the species of timber harvesting and other associated activities such as roading, fire and disease. To address this, an initial 1995 survey effort aimed at determining population distribution and assessing the abundance of individuals in different populations (Hopkins 1995). Records of H. calycina prior to the 1995 survey indicated that it had a restricted distribution in the Scamander area on Tasmania's northeast coast. Known pre1995 sites, detailed in Hopkins (1995), included Mt Echo, Loila Pinnacle, Pyramid Hill and southern Skyline Tier (sites 3/4/5 Map 19 in Barker (1994)), and a population south of Scamander at McIntyres Ridge (G.E. Williams pers. comm. 1994). The extensive 1995 survey by Hopkins (1995) and subsequent follow-up surveys occurred while timber harvesting was active in Eucalyptus sieberi forests. 
This paper reports on three surveys undertaken to monitor the population distribution and abundance of $H$. calycina and determine how its population density has changed over 23 years of monitoring, in response to fire and the absence of active management. We discuss threatening processes to the species and provide recommendations for future management.

\section{METHOD}

\section{Study area}

The study focused on an area of approximately $544 \mathrm{~km}^{2}$ which encompassed previously known locations of $H$. calycina in northeastern Tasmania (Hopkins 1995). The study was confined to $E$. sieberi forests, which are restricted to northeast lowland and upland slopes (to $500 \mathrm{~m}$ elevation), predominantly on Ordovician sediments (Mathinna Beds), Devonian granites and Jurassic dolerite (Grant et al. 1995) (fig. 1).
Soils derived from Ordovician sediments (Mathinna Beds) are typically poor in nutrients, shallow and free draining with a poor capacity to hold moisture. These areas are characterised by dramatic sharp ridges with steep slopes leading to deeply incised gullies with ferns and typically contain $E$. sieberi forests that are open dry sclerophyll forest with a secondary canopy of Allocasuarina littoralis (Salisb.) L.A.S. Johnson, and a very sparse lower understorey layer of various shrub species including Pultenaea gunnii Benth. Descriptions of vegetation can be found in TASVEG (Kitchener \& Harris 2013).

The study area has a history of mining (predominantly tin and some gold) dating back to the 1880s (Bacon 2013) with many mineshafts and terracing still evident in the district. Mining is not presently active in the area, although an exploration license is current for Pyramid Hill (Tasmanian Government 2017). Some forestry activities would have been associated with mining; but since 1970 most forestry operations comprised logging of native forest for sawlogs and pulpwood, and conversion of some sites (generally on less insolated slopes) to plantations of

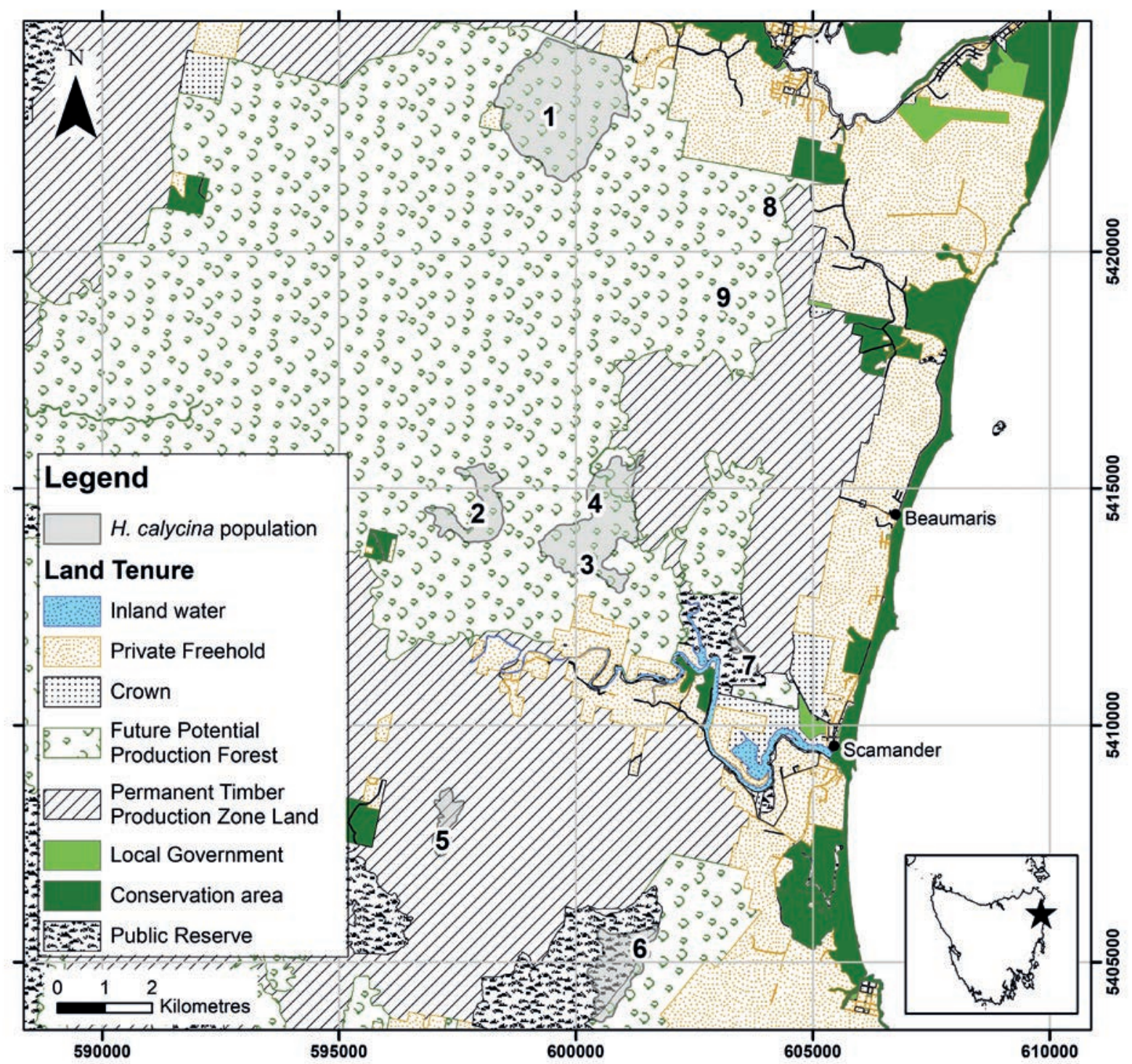

FIG. 1. - Hibbertia calycina populations in northeastern Tasmania. Numbers refer to ridgelines (see table 1); 1. Mt Echo, 2. Loila Pinnacle/Wolfram, 3. Pyramid, 4. Orieco, 5. Bolpeys, 6. Mclntyres East and Mclntyres West, 7. Skyline, 8. Flagstaff, 9. Basin Creek. Inset: location of $H$. calycina in Tasmania. 


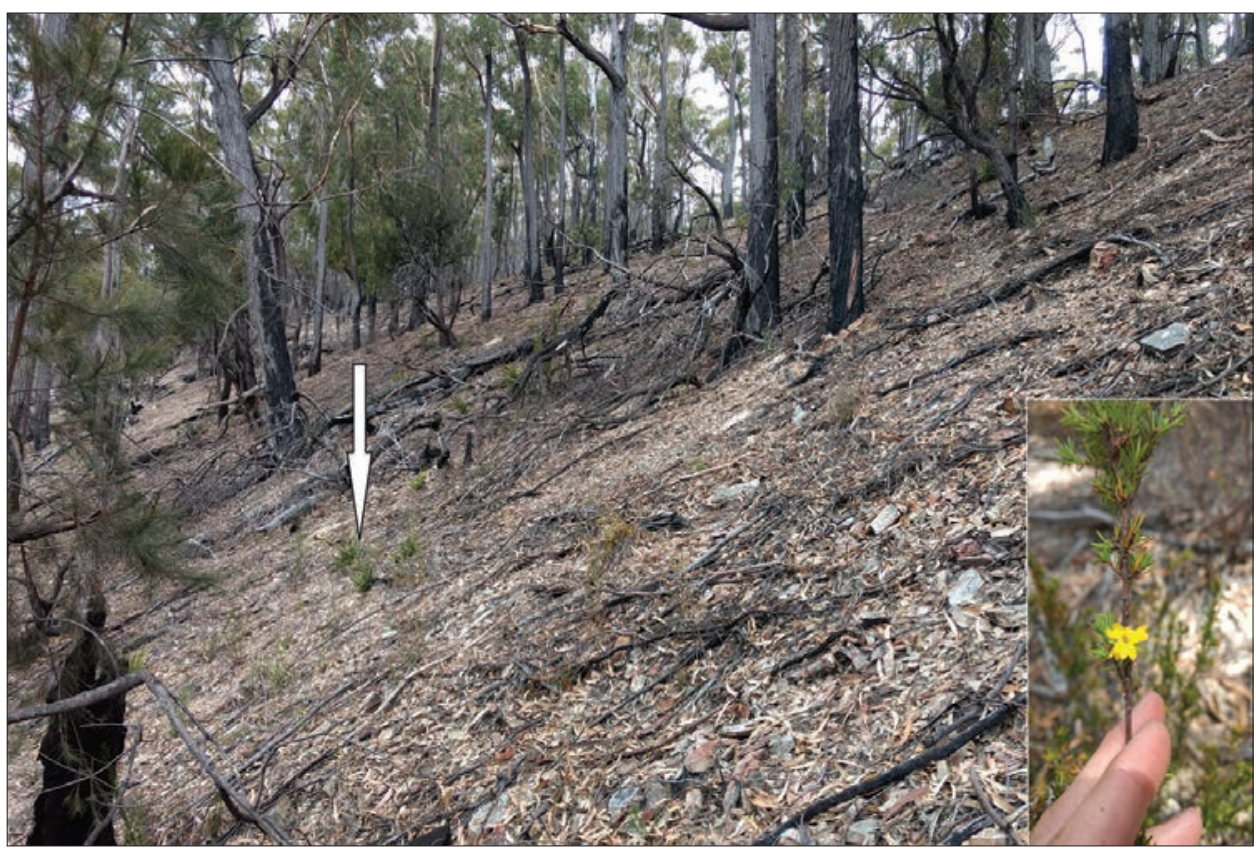

PLATE 1 - Hibbertia calycina in situ (note the very open understorey typical of most sites supporting the species), with inset showing the distinctive (yellow) flowers, and leaf shape and arrangement. Arrow indicates an $H$. calycina plant.

Pinus radiata D.Don. There were few forestry operations in potential $H$. calycina habitat in native forest for years 1995-2018. Invasive species (plant and animal) are not common, except for $P$. radiata wildlings near plantations and the soil pathogen Phytophthora cinnamomi that occurs in this area (Schahinger et al. 2003).

Northeastern Tasmania has a relatively mild climate with a mean minimum/maximum temperature for January of $12.7 / 22.1^{\circ} \mathrm{C}$ and for July of $4.5 / 13.8^{\circ} \mathrm{C}$ (Bureau of Meteorology 2018). Rainfall averages $689 \mathrm{~mm}$ per annum and rainfall events are irregular; mean monthly rainfall ranges from a low of $45.3 \mathrm{~mm}$ (February) to a high of 69.0 mm (April) (Bureau of Meteorology 2018). There are no predominant winter or summer peaks in rainfall although occasional low-pressure systems off Tasmania's east coast can result in intense rainfall events (up to $150 \mathrm{~mm}$ in 48 hours; Bureau of Meteorology 2018). Rainfall irregularity means that intense periods of rainfall are often followed by long dry periods (Neyland \& Askey-Doran 1996).

\section{Distribution and density of $H$. calycina}

The past and present distribution of $H$. calycina was investigated using historical accounts (including published literature), reports, photographs, verification of herbarium specimens, retrieval and verification of unpublished data and mapping. Due to changes in technology there are limitations with previous mapping. However, these data provide useful baselines upon which to reference and compare present data and mapping. Field surveys to determine the extent and size of $H$. calycina populations were undertaken in 1995 , with follow-up surveys in 2003/04 and 2017/18 focused on monitoring the 1995 survey populations, and additional discoveries. A 'clump' was defined as a group of $H$. calycina individuals no more than $50 \mathrm{~m}$ apart. During these surveys, movement and access were restricted where very steep terrain was encountered and some plants may have been missed.

The first survey, between April and September 1995, surveyed approximately 26 ridgeline systems by vehicle with regular on-foot ground checking (where visibility was low due to topography and/or understorey) for the presence of H. calycina (fig. 1). The target species was located on eight of these ridgelines and upper slopes. Sketch maps of $H$. calycina clumps were produced by hand-drawing polygons onto 1:25,000 scale maps. Calculations of boundaries were later checked against maps and aerial photos where available. There was some variability in the detail of the data collected between clumps.

The areas identified as having $H$. calycina in the 1995 sketch maps were re-surveyed in October 2003 and January 2004, apart from a portion of one ridgeline which had been burnt (appendix 2d: Oreico36). One new ridgeline was surveyed due to anecdotal information (Flagstaff). Again, sketch maps of the nine known ridgeline populations were drawn and later digitised into a Geographical Information System (GIS) in 2017. Detailed data on the abundance of $H$. calycina was collected for some but not all nine clumps.

In November 2017 and February 2018 only eight of the nine known ridgelines were re-surveyed due to logistical constraints. During this survey the location and boundaries of all known $H$. calycina clumps were mapped using GPS techniques, and collection of positional data for individual H. calycina was undertaken in November 2017 and April 2018 using a Garmin Etrex handheld GPS unit accurate to 5-15 m. Two operators (PAMT and MW) each moved a GPS handheld unit around a $H$. calycina clump, recording a point for every plant where possible: at some sites where many individuals were present, the final number of plants recorded was an estimate, not an absolute count. Plant height for some clumps were recorded with height data provided in appendices 3 and 5 .

The number of $H$. calycina plants per ridgeline were summed for each survey event and compared. The small number of samples per ridgeline restricted statistical analyses. The size of each $H$. calycina population was visually compared over time, but only a brief overview is 
provided in the results. The density of $H$. calycina plants (per hectare) was calculated for each clump in 2017/18. Spatial data were analysed in a GIS database (ArcMap) and Excel spreadsheet.

\section{Site disturbance: Phytophthora and fire}

For each clump, the year of the most recent fire, fire frequency and mean fire interval were determined from the surrounding area, historical records and local knowledge (e.g., Neyland \& Askey-Doran 1996, G. Williamson pers. comm. 2018). Fire frequency was the number of times that fires occurred within a site between 1975 and 2018 (43 years). The mean fire interval for a clump was calculated (when more than one fire was recorded for a site) as the sum of the years between each fire event divided by the number of fire events for that clump. Where only one fire event was recorded, the mean fire interval was unknown. The impact of fire on $H$. calycina was assessed by considering how the density of $H$. calycina related to year of the most recent fire and fire interval. All population analyses were performed within the statistical freeware R v.3.4.1 (R Core Team 2019) with packages ggplot2 (version 3.3.2, Wickham 2016) and dplyr (version 1.0.0, Wickham et al. 2020).

The suspected presence of Phytophthora cinnamomi was recorded by noting symptoms during the 2003/04 survey if $H$. calycina and/or other susceptible species (indicator species; Schahinger et al. 2003) were showing signs of disease (i.e., symptoms including dead plants, dieback, yellowing of foliage) where other resistant plants looked healthy. In 2017/18 two sites were tested for $P$. cinnamomi where $H$. calycina plants with yellowing foliage were identified. Tests were done by collecting $5 \mathrm{~cm}^{3}$ soil samples from around the roots of three yellowing $H$. calycina individuals and then combining the samples for each site before laboratory processing. Soil was analysed for the presence/absence of $P$. cinnamomi using the methods of Ribeiro (1978).

\section{RESULTS}

\section{Distribution}

In $2017 / 18$ a total of nine $H$. calycina populations were documented with an estimated 15,267 plants, in an area of occupancy of $0.43 \mathrm{~km}^{2}$ and area of extent measuring $95 \mathrm{~km}^{2}$. The data suggest there has been an increase in the number of ridgeline $H$. calycina populations over time; however, this increase may be attributed to improved recording and searching techniques with greater precision over time. The 1995 survey found a total of 33 distinct clumps of $H$. calycina on 8 of the 26 ridgelines surveyed (fig. 1, table 1 , appendix 4). Of the 1995 survey clumps, in 2003/04 plants of one Oreico clump were labelled 'extinct', and one clump at Flagstaff was added (fig. 1, table 1, appendix 4). Thus in 2003/04 a ninth ridgeline was added but the number of clumps remained the same (33). The number of clumps increased to 41 across the same nine ridgelines in 2017/18 (table 1, fig. 1). In addition to recording all clumps

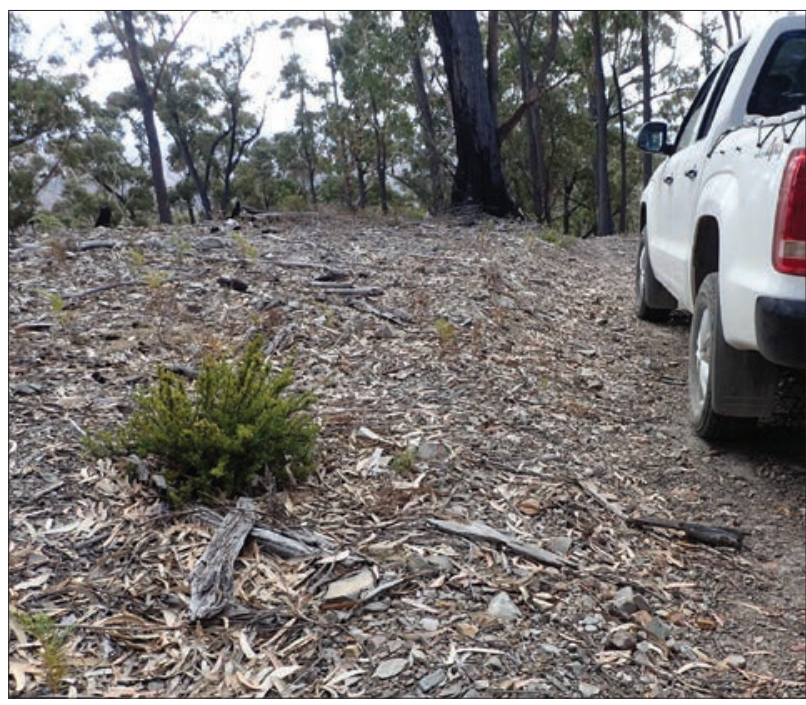

PLATE 2. - Hibbertia calycina growing in a road verge at Mt Echo.

documented in 2003/04, the 2017/18 survey recorded an additional clump at Basin Creek.

Where it was possible to compare, the boundary maps for the three survey periods largely found close agreement in the boundaries of $H$. calycina populations over time. However, some clumps had changed, with some single clumps in 1995 becoming multiple clumps (e.g., Pyramid26-29), some clumps had expanded and combined (e.g., Mt Echo1, Loila Pinnacle/Wolfram5, Loila Pinnacle/Wolfram12, Oreico32, McIntyres East37, table 1, appendix 2), and at 15 clumps the range expanded and plants were observed right up to the road verge (e.g., MtEcho1, pl. 2). Of the four clumps surveyed at Oreico in 1995, plants of one clump (Oreico36 of Hopkins 1995) were noted as extinct in 2017/18 (table 1 , appendix 2d). At some clumps where $H$. calycina occurs on a slope, populations appear to extend directly downslope over time, perpendicular to the contour (e.g., Mt Echo1, Pyramid30, Oreico32, Oreico33, appendix 2a, c and d).

\section{Density}

There is evidence of an overall increase in the number of H. calycina plants over time (fig. 2). In 1995 there was a very rough estimate of $4,500 \mathrm{H}$. calycina plants. In 2003/04 this had increased to over 7000 plants, and the 2017/18 survey recorded a total of 15,267 $\mathrm{H}$. calycina plants (table 1 ), averaging a density of 311 plants/ha in the clumps. However, it is likely that for all surveys the total number of plants is an underestimate; many plants on the larger ridgelines may have been missed and it is likely that in some instances a single logged data point represents more than an individual plant. While very high densities of plants were found in many clumps (table 1), the size of these clumps was typically very small. For clumps over 1 ha in size, the density of $H$. calycina ranged from 89-565 plants/ha (table 1 ). 


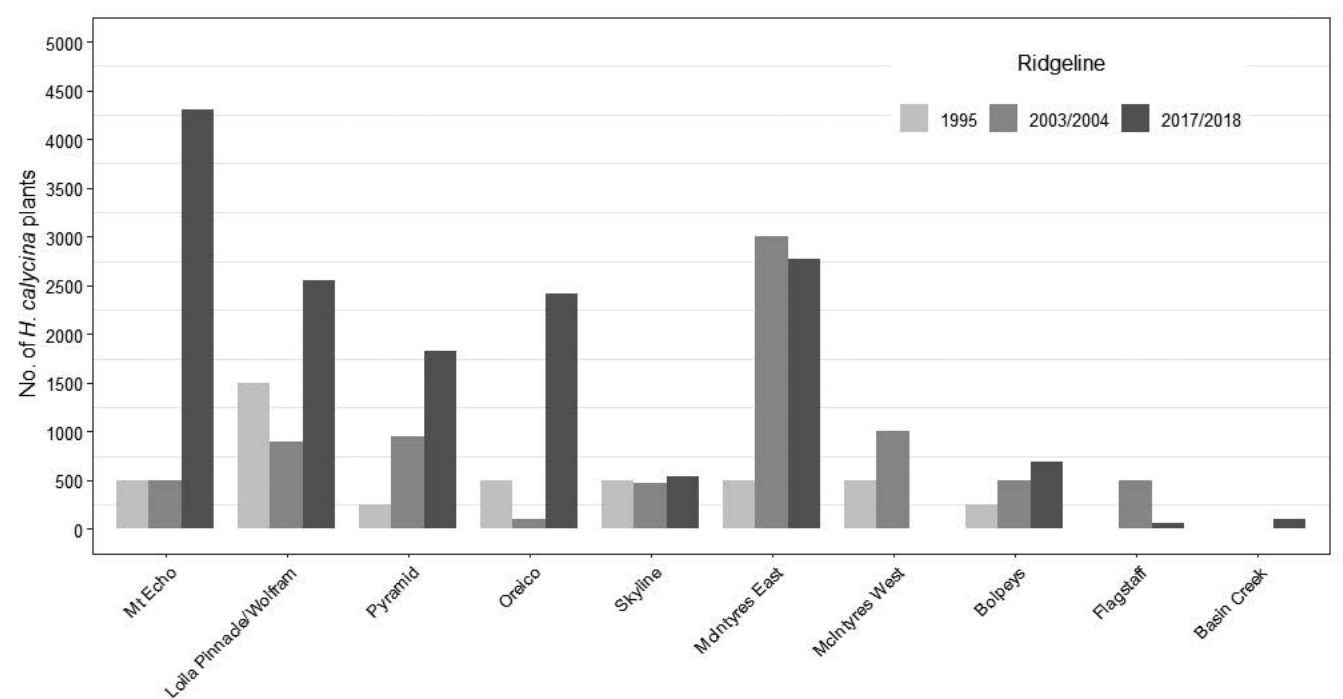

FIG. 2. - Number of Hibbertia calycina plants recorded during each survey by ridgeline. Note: some incomplete data, e.g., Mclntyres West, Flagstaff and Basin Creek. Maximum value indicated where a range is given (see table 1 for details).

\section{Impact of fire}

Signs of historical or recent fire (e.g., fire-hollows or charcoal on trees) were present at all clumps and time since the most recent fire ranged between 2006 and 2017 (table 1). Our results suggest that fire can, but does not always, kill $H$. calycina, and regeneration usually occurs after fire where fire severity is low. Flagstaff 40 was visited before and after being burnt in 2017. In June 2019, no individuals were found at the clump location. Four visits after June 2019 and before April 2020 recorded a total of two living plants, presumably from seed, and no re-sprouting plants (MW pers. obs. 2020). Similarly, signs of high severity fire (large, dead trees with fire-hollowed bases) were found at
Oreico in 2017/18 and the plants of the Oreico36 clump of the 1995 survey were deemed extinct in 2003/04. Our observations of $H$. calycina populations found mean height of plants varied with time since the most recent fire (e.g., Skyline35, McIntyres37, Pyramid30, appendix 3) and the density of $H$. calycina plants in a clump appears to increase with time since the most recent fire (fig. 3).

The fire frequency varied. For Mt Echo the fire frequency was four fires per -50 years and for McIntyres West it was two fires per -50 years (appendix 4). The mean fire interval ranged from four years (Mt Echo3) to 30 years (McIntyres38) with an overall mean of 18 years \pm 3 SE (table 1, fig. 4). A longer mean fire interval appears to relate to a higher density of $H$. calycina (fig. 4). Frequent

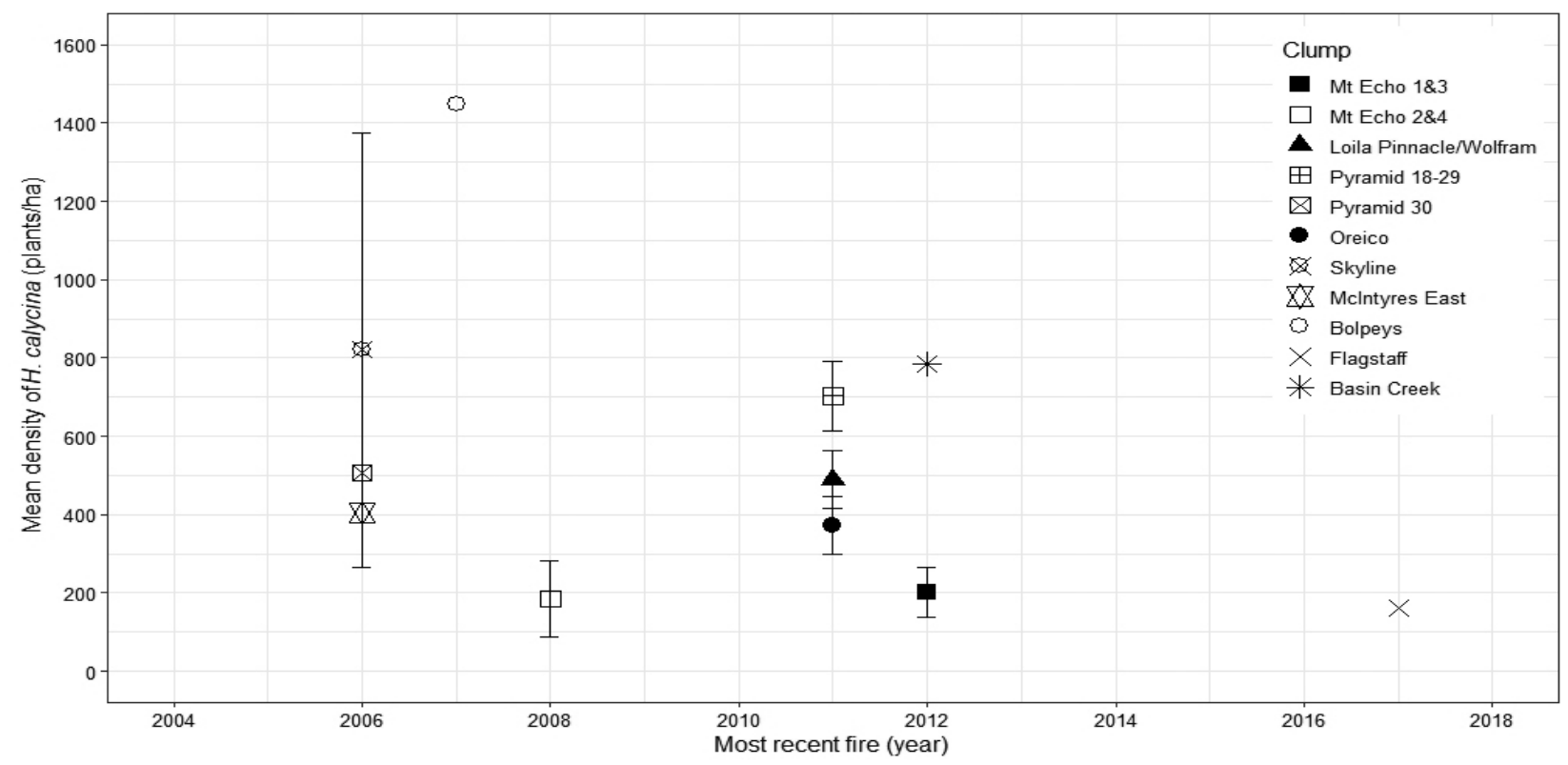

FIG. 3. - Mean density of Hibbertia calycina ( \pm SE) (plants/ha) recorded by clump grouped by ridgeline and most recent fire (year), for the 2017/2018 survey. Mt Echo 1\&3 (n=2); Mt Echo 2\&4 (2); Loila Pinnacle/Wolfram (12); Pyramid (12); Oreico (4); Skyline (2); Mclntyres East (1); Bolpeys (1); Flagstaff (1); Basin Creek (1). 
TABLE 1 - Population data of Hibbertia calycina from all surveys.

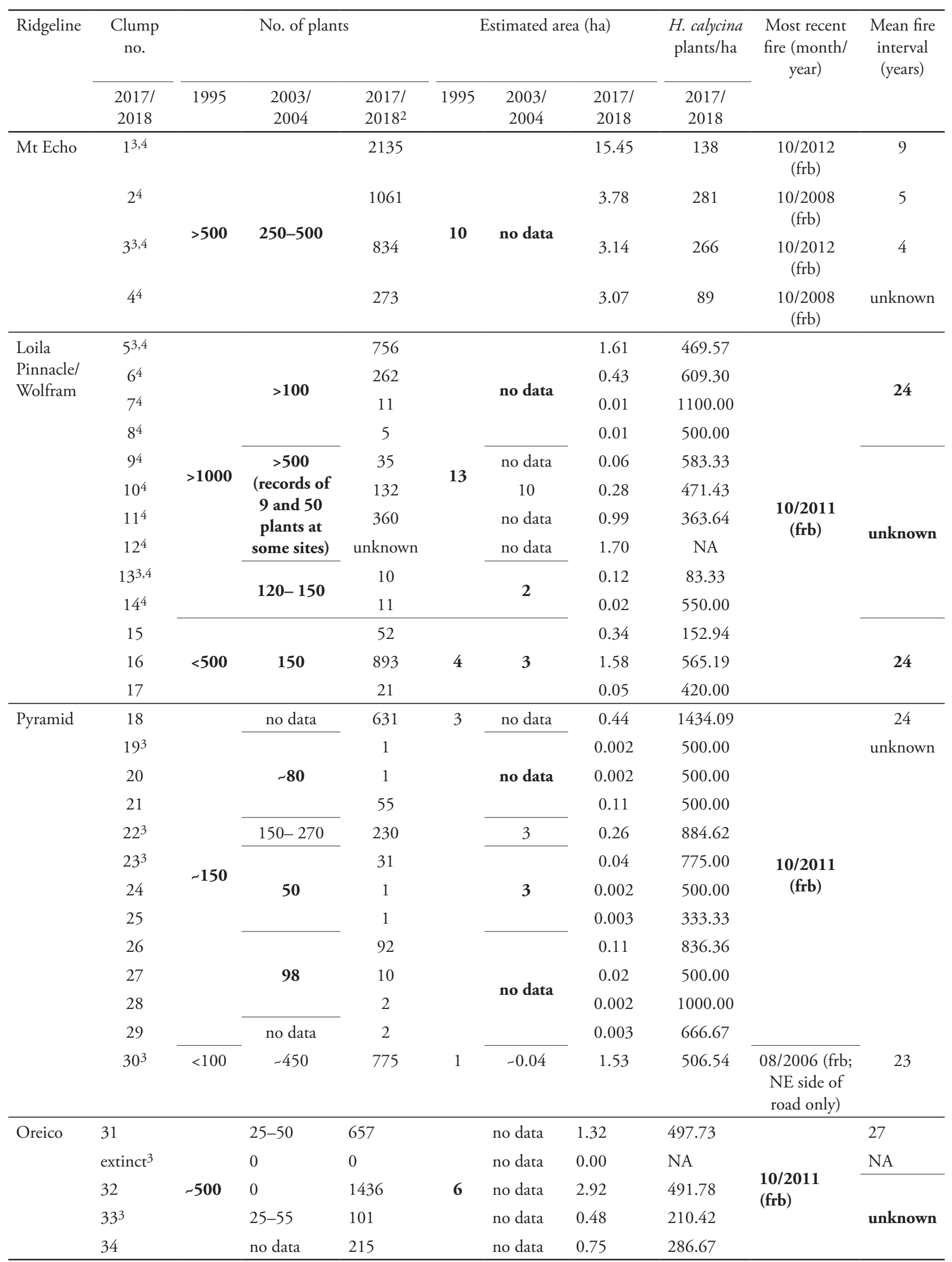


TABLE 1 - cont.

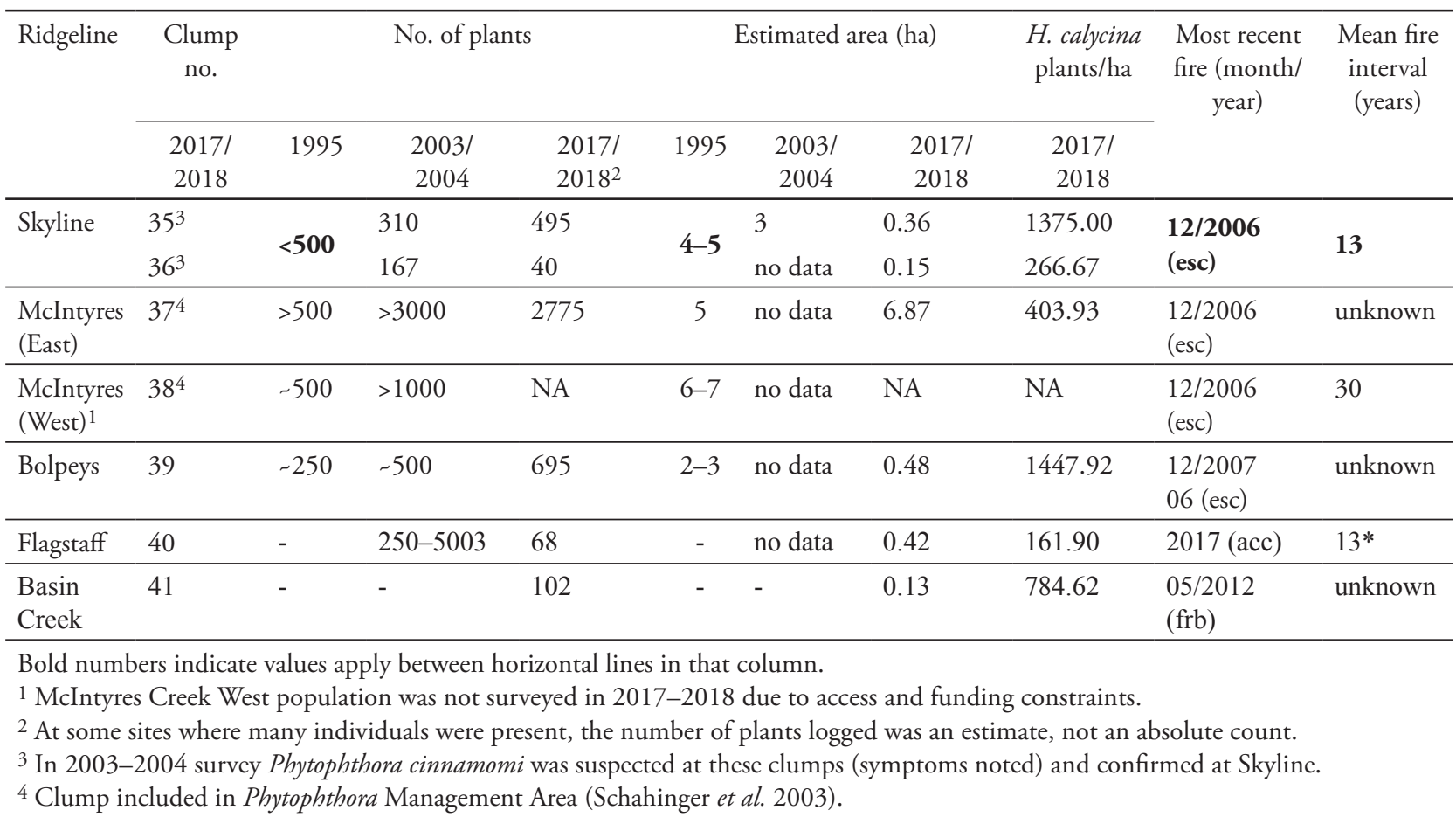

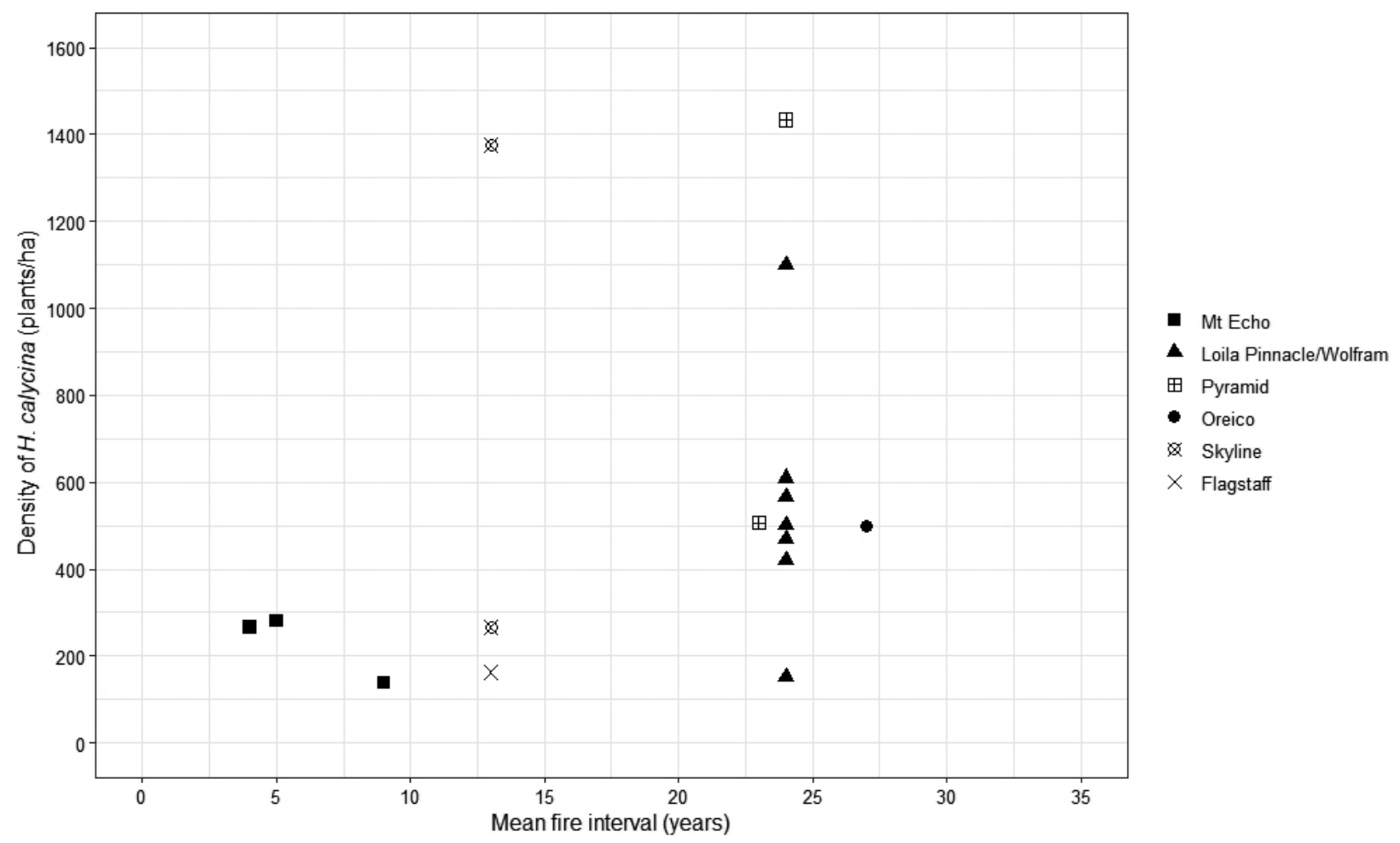

FIG. 4. - Density of Hibbertia calycina (plants/ha) by ridgeline recorded during the 2017/2018 survey against the mean fire interval (years) for that clump. See table 1 for details. 
but patchy fires do not appear to significantly impact the area and density of $H$. calycina clumps (e.g., Mt Echo).

\section{Phytophthora cinnamomi}

The 1995 survey identified P. cinnamomi was already threatening the viability of $H$. calycina clumps. The 2003/04 survey only confirmed P. cinnamomi from one site (Skyline), with another 12 sites suspected as being infected by sighting one or many plants showing symptoms of infection (table 1). While in $2017 / 18$ two sites were tested for P. cinnamomi (MtEcho and Loila Pinnacle/Wolfram), both were negative. A search of the Atlas of Living Australia (2020) records three sightings of $P$. cinnamomi from sites at which $H$. calycina is present (Mt Echo in 2001 by R. Schahinger record \# 526938; Flagstaff in 2003 by A. Woolley record \#998942; Skyline in 1973 by C. Palzer \# 526097).

\section{DISCUSSION}

The present study suggests there has been an increase in the number of individual $H$. calycina plants and clumps between 1995 and 2018, a period when the main disturbance in the area was wildfire. The number of known $H$. calycina clumps was 33 in 1995, and this increased to 41 in 2017/18. This change may in part be attributed to an additional ridgeline with $H$. calycina being located and some 1995 clumps 'splitting' over time (although others joined, and one clump went extinct). It is possible that the increase in number of clumps is also due to greater sampling efforts with time. Regardless of the reason, the results suggest that the number of clumps has remained relatively stable over this time period.

A comparison of the 1995 sketch maps with the 2017/18 GIS maps suggests that many clumps have expanded downslope over time (MW, KH \& PAMT pers. obs.). This is possibly a product of heavy rain causing seed to wash downslope, together with suitable temperature and moisture conditions for germination (Schatral et al. 1997).

\section{Fire}

While the study area has a history of mining and commercial timber harvesting, the only disturbance occurring during the study period was wildfire. The fires in the area have been patchy, meaning there is some variability in the fire history of the different clumps. The results from the current study indicate that severe fire can eliminate populations. Elsewhere, presumably after less severe fire, populations recover. One clump (Flagstaff) was burnt in 2017 and revisited about six months later and there were no signs of plants regenerating until three years after the fire when two seedlings were recorded. Another clump (Oreico36) displayed evidence of high intensity fire in 1995 and the $H$. calycina plants at the site are now considered extinct. In comparison, successful recruitment and spread of plants was evident at long unburnt clumps, such as Mt Echo2 and Mt Echo4 (MW pers. obs.). H. calycina does not require burning for regeneration of seed-set and infrequent fire regimes are thought to favour plant recruitment and re-sprouting from lignotubers (Bell et al. 1993).

There is little information on the fire regimes of dry sclerophyll E. sieberi forests of northeastern Tasmania prior to European settlement (Crawford et al. 1962) or for the early years of European colonisation. In more recent times, highly flammable and fire resistant (regenerates post-fire) E. sieberi forests are little impacted by a single or repeated understorey fire (Collins 2020). However, repeated short fire intervals (i.e., < 10 years) may cause long-term changes, converting the understorey of forests dominated by epicormic sprouting $E$. sieberi to an alternative state (Pyrke \& Marsden-Smedley 2005, Fairman et al. 2016, Collins 2020). In the past 30 years Tasmanian E. sieberi forests have been subject to a fuel reduction burn program with a recommended seven-year return cycle, to reduce fuel loads and risk to infrastructure (regional towns, mining and commercial timber harvesting operations) (Neyland \& Askey-Doran 1996). This is shorter than many of the ecological burning regimes used elsewhere in Australia such as the 20-25 years minimum inter-fire period for box-ironbark forests (Neyland \& Askey-Doran 1996, Tolsma et al. 2010). Results in the present study suggest H. calycina appears to benefit from long (approx. 18-year) fire return cycles and can recover from relatively intense fire via re-sprouting from lignotubers and epicormic growth (Hopkins 1995).

Another disturbance related to fire is the maintenance of vehicular tracks to facilitate access for fire prevention and fuel reduction; these tracks are mainly located on ridgelines. For example, the clump that currently straddles Trout Road (Pyramid30, table 1) is subject to periodic road grading that results in gravel and spoil being pushed downhill over individuals of $H$. calycina. The 1995 and 2003/04 survey notes mentioned that the Mt Echo, Oreico and Pyramid ridgeline clumps were found in areas of disturbance (Hopkins 1995); the 2017/18 survey made similar observations. Whilst plants can be eliminated due to track grading (e.g., Pinnacle/Wolfram13 and Pinnacle/ Wolfram14, table 1, MW, KH and PAMT pers. obs.) in the long term, the present study found that $H$. calycina successfully established in areas where soil disturbance from past mining, roading and track creation from timber harvesting or general maintenance has created a possible seedbed suitable for colonisation (pl. 2).

\section{Forestry}

In addition to fire, $H$. calycina populations have been subject to other disturbance factors since European settlement. While E. sieberi forests were harvested in the 1990s, no commercial timber harvesting has taken place where $H$. calycina occurs in more recent times. Unregulated firewood collection is undertaken extensively across ridgelines and upper slopes in the range of $H$. calycina, with virtually all ridgeline populations of the species dissected by some form of track, now used for firewood collecting. 


\section{Phytophthora}

Phytophthora cinnamomi is a soil-borne plant pathogen that attacks the root system of susceptible plants and reduces plant health by restricting uptake of water and nutrients. Activities such as recreational vehicles and road maintenance for fire access have the potential to disturb soil and introduce $P$. cinnamomi to populations. In Tasmania, P. cinnamomi is widely distributed throughout climatically suitable areas (see Schahinger et al. 2003, figs 2 and 3) and the area known to support $H$. calycina is potentially able to support the pathogen (Podger et al. 1990, Schahinger et al. 2003). The 1995 survey identified P. cinnamomi was already threatening the viability of clumps of $H$. calycina (Hopkins 1995). The 2003/04 survey suspected $P$. cinnamomi infection was present at 12 clumps and confirmed on one ridgeline. In $2017 / 18$ there were signs of $P$. cinnamomi infection in the area. $H$. calycina in full sun were observed with leaves yellow in colour on plants that appeared otherwise healthy while plants in the shade displayed no obvious yellowing leaves. On the lower slopes of Mt Echo, H. calycina of multiple ages (from seedlings through to plants over $1 \mathrm{~m}$ tall) were found growing amongst a 'wave' of dead/dying Xanthorrhoea australis R.Br., which is usually a tell-tale sign of $P$. cinnamomi. However, the two tests done in 2017/18 were both negative for $P$. cinnamomi.

$H$. calycina is known to be susceptible to P. cinnamomi because in 1995 live seedlings were found amongst dead and dying $X$. australis at Mt Echo and laboratory tests confirmed death of two plants grown from cuttings died after 81 days, from infection by $P$. cinnamomi in the roots (Barker \& Wardlaw 1995). In 2001 P. cinnamomi was recorded as a 'sighting' from Mt Echo. The susceptibility of Hibbertia species to P. cinnamomi varies enormously (Weste \& Ashton 1994, Reiter et al. 2004). The sample sizes of Barker and Wardlaw (1995) and the present study were small meaning the true susceptibility of $H$. calycina to $P$. cinnamomi is uncertain. Given potential for roading and illegal firewood cutting to facilitate pathogen spread (e.g., Mt Echo, see Barker 1994, Schahinger et al. 2003), uncertainty of spread in a changing climate (Commonwealth of Australia 2018), and that P. cinnamomi is one of two plant diseases considered at the forefront of conservation concerns in Australia (Burgess et al. 2017, Silcock \& Fensham 2018), actions to minimise or exclude infection risk by $P$. cinnamomi on $H$. calycina are warranted until larger sample sizes are similarly tested. Sixteen $H$. calycina clumps are found within three Phytophthora Management Areas (PMAs) (table 1; Barker et al. 1996, Schahinger et al. 2003) where there are restrictions on actions such as soil movement (roading) that facilitate pathogen spread.

\section{Conservation status}

H. calycina was listed on the Tasmanian Threatened Species Protection Act 1995, along with over 400 other plant species, at the commencement of the Act. For many of these plant species, including $H$. calycina, a guide provided brief explanatory information regarding the recommendation to add to the Act (Flora Advisory Committee 1994). The species listing was supported by expert advice prior to Hopkins (1995). This listing is as per criterion 3: vulnerable, criterion $\mathrm{B}$, with the following additional criteria applying: 1: severely fragmented or known to exist at no more than ten locations and, criterion 3.c: extreme fluctuations in number of locations or subpopulations; and, criterion 3.d: extreme fluctuations in number of mature individuals.

The results of the present paper estimated an extent of occurrence of $95^{2} \mathrm{~km}$ with an area of occupancy of $0.43 \mathrm{~km}^{2}$, demonstrating that the current listing of $H$. calycina as vulnerable is narrowly acceptable, qualifying under criterion $\mathrm{B}$ (extent of occurrence estimated to be less than $2,000 \mathrm{~km}^{2}$ or area of occupancy estimated to be less than $0.5 \mathrm{~km}^{2}$ ) and additional criteria 1 and 3.c. The total population remains relatively small, and restricted, and it could be argued that the population is partially fragmented and occurring at less than 10 locations, meeting criterion B1. Fluctuations are possible where stochastic risk of fire and threatening processes such as $P$. cinnamomi are present (criterion 3.c). Our results show that populations of $H$. calycina are not declining (criterion B2). The present study recorded over 15,000 individuals but did not quantitatively record maturity. Therefore, the requirement to meet vulnerable through criterion 3.d. and criterion $\mathrm{C}$ (a decline in the number of mature individuals having a population containing less than 10,000 mature individuals) cannot be confirmed.

With no population decline, and if the majority of individuals are considered to be mature, a qualification as vulnerable is tenuous and $H$. calycina would qualify as rare under Section 15(4) of the Act where the extent of occurrence is less than $80 \times 80 \mathrm{~km}$ or $2000 \mathrm{~km}^{2}$; the area of occupancy is not more than $0.5 \mathrm{~km}^{2}$ (50 hectares), with risks due to threatening processes such as $P$. cinnamomi and fire in a changing climate over the extent of its range. It is possible that $H$. calycina is a species that has always been localised and uncommon in Tasmania, with little loss of localised, preferred habitat. However, as our estimate of individuals did not specifically identify maturity, as a precautionary approach we recommended maintaining the current vulnerable status until another more thorough population estimate noting maturity is undertaken.

We estimate through the $2017 / 18$ data that over 2,500 individuals are securely reserved (Scamander Regional Reserve [Skyline] and German Town Regional Reserve [McIntyres]); a moratorium on production forestry in Future Potential Production Forest was lifted in 2019 (appendix 4). At the time of the first survey in 1995, two ridgeline populations were reserved: Skyline and McIntyres West. The remaining ridgelines occurred in Special Management Zones open to production forestry on public land. Since 1995 no changes to tenure have been made (although some changes to reserve managers have occurred) with the exception of McIntyres East, where west of the ridgeline is reserved (the greater part of the population). Regardless of reservation, the stochastic risk of fire cannot be discounted as previously discussed, and the Tasmanian Forest Practices system would afford 
protection should forestry operations be authorised in areas which contain any records of the species.

\section{CONCLUSION}

H. calycina is a species highly tolerant of dry, fire-prone environments, appearing to maintain stable population sizes in the face of regular fire events and a lack of active management. Repeated surveys over time found some clumps of plants have gone extinct, likely due to intense fires, indicating protection from frequent, intense fires may be required. Over time, the number of clumps increased, potentially due to greater sampling effort. Whilst $H$. calycina appears to successfully establish on past soil disturbance such as road verges affected by grading, roading to facilitate fire access has the potential to eliminate the species from an area. The susceptibility of the species to infection by $P$. cinnamomi requires further investigation; meanwhile current Phytophthora management areas provide some protection of $H$. calycina and associated $P$. cinnamomi susceptible species. Elsewhere within the range of this species, applying hygiene measures to prevent and minimise spread of P. cinnamomi and minimising road grading should be implemented. Overall, current $H$. calycina populations are stable. As a precaution, current threatened species status should be maintained until a more thorough assessment of populations, including maturity, is undertaken.

\section{CONFLICT OF INTEREST AND ACKNOWLEDGEMENTS}

The authors declare no conflicts of interest. The initial surveys by K. Hopkins were financially supported by the Eastern Tiers District of Forestry Tasmania (now Sustainable Timber Tasmania) with logistical support from staff of the Forest Practices Board (now Forest Practices Authority) and Forestry Tasmania. Roy Skabo, Stephen Casey, Emily Wapstra, James Wapstra and Phil Barker assisted with fieldwork. Nita Ramsden at Sustainable Timber Tasmania performed the testing for Phytophthora cinnamomi. Alex Buchanan (formerly of the Tasmanian Herbarium) provided useful discussion on the earlier collections from the 1980s. Staff of the Tasmanian Herbarium (Miguel de Salas, Kim Hill) provided access to specimens and their database of collection information. Hellmut Toelken provided information on possible seed dispersal mechanisms and the taxonomic status of the species. Grant Williamson (University of Tasmania) provided fire history. The figures and tables were prepared by Perpetua Turner, Anne Chuter, and Sarah Munks commented on drafts of the manuscript. We also thank Sally Bryant, Mick Brown and Louise Gilfedder for their constructive reviews which greatly improved the manuscript.

\section{REFERENCES}

Atlas of Living Australia 2020: Atlas of Living Australia, www.ala. org.au (accessed 4 June 2020).

Bacon, C.A. 2013: A Tasmanian Mining History Timeline. Tasmanian Geological Survey Record 2013/10. Mineral Resources Tasmania. Department of Infrastructure, Energy and Resources, Hobart. www.mrt.tas.gov.au/mrtdoc/dominfo/ download/UR2013_10/UR2013_10.pdf (accessed 7 May 2019).

Barker, P.C.J. 1994: Phytophthora cinnamomi: The susceptibility and management of selected Tasmanian rare species. Forestry Tasmania and Australian Nature Conservation Agency. Hobart: $104 \mathrm{pp}$.

Barker, P.C.J. \& Wardlaw, T.J. 1995: Susceptibility of selected Tasmanian rare plants to Phytophthora cinnamomi. Australian Journal of Botany 43: 379-386.

Barker, P.C.J., Wardlaw, T.J. \& Brown, M.J. 1996: Selection and design of Phytophthora management areas for the conservation of threatened flora in Tasmania. Biological Conservation 76: 187-193.

Bell, T.D., Plummer, J.A. \& Taylor, S.K. 1993: Seed germination ecology in south western, Western Australia. The Botanical Review 59: 34-69.

Bureau of Meteorology 2018: 'Average annual, seasonal and monthly rainfall.' www.bom.gov.au/jsp/ncc/climate_averages/ rainfall/index.jsp and www.bom.gov.au/jsp/ncc/climate_ averages/temperature/index.jsp (accessed 10 May 2019).

Burgess, T.J., Scott, J.K., McDougall, K., Stukely, M.J.C., Crane, C., Dunstan, W.A., Brigg, F., Andjic, V., White, D., Rudman, T., Arentz, F., Noborum, O. \& Hardy, G.E.S. 2017: Current and projected global distribution of Phytophthora cinnamomi, one of the world's worst plant pathogens. Global Change Biology 23: 1661-1674.

Burgman, M.A., Keith, D., Hopper, S.D., Widyatmoko, D. \& Drill, C. 2007: Threat syndromes and conservation of the Australian flora. Biological Conservation 134: 73-82.

Collins, L. 2020: Eucalypt forests dominated by epicormic resprouters are resilient to repeated canopy fires. Journal of Ecology 108: 310-324.

Commonwealth of Australia 2015: Threatened Species Strategy. Canberra. www.environment.gov.au/biodiversity/ threatened/publications/threatened-species-strategy (accessed 7 May 2019).

Commonwealth of Australia 2018: Threat abatement plan for disease in natural ecosystems caused by Phytophthora cinnamomi. www.environment.gov.au/system/files/resources/eelf3b9f6e2e-4a01-86f3-6abb167fb443/files/tap-phytophthoracinnamomi-2018.pdf (accessed 7 May 2019).

Craigie, V., Reynolds, D., Walsh, N., Mueck, S., James, E., Tonkinson, D. \& Rudolph, P. 2018: Spiny rice-flower small, unassuming but with many friends, pp. 43-53. In Garnett, S., Latch, P., Lindenmayer, D. \& Woinarski, J. (eds): Recovering Australian Threatened Species, CSIRO Publishing, Clayton South: 342 pp.

Crawford, E.C., Ellis, W.F. \& Stancombe, G.H. 1962: The diaries of John Helder Wedge, 1824-1835. Royal Society of Tasmania, Hobart: 100 pp.

DEE (Department of Environment \& Energy) 2020: EPBC Act List of Threatened Flora. www.environment.gov.au/cgi-bin/ sprat/public/publicthreatenedlist.pl?wanted=flora (accessed 20 January 2020).

de Salas, M.F. \& Baker, M.L. 2019: A Census of the Vascular Plants of Tasmania, including Macquarie Island. Tasmanian Herbarium, Tasmanian Museum and Art Gallery, Hobart: 156 pp. www.tmag.tas.gov.au/__data/assets/ pdf_file/0005/179915/2018_Census_of_Tasmanian_ Vascular_Plants.pdf (accessed 7 May 2019).

Dirzo, R. \& Raven, P.H. 2003: Global state of biodiversity and loss. Annual Review of Environmental Resources 28: 137-67. 
DPIPWE (Department of Primary Industries, Water and Environment) 2000: Threatened Species Strategy for Tasmania. Nature Conservation Branch, Department of Primary Industries, Water and Environment, Hobart: 30 pp. https://dpipwe.tas.gov.au/Documents/threatspstrat.pdf (accessed 7 May 2019).

Fairman, T.A., Nitschke, C.R. \& Bennett, L.T. 2016: Too much, too soon? A review of the effects of increasing wildfire frequency on tree mortality and regeneration in temperate eucalypt forests. International Journal of Wildland Fire 25: 831-848.

Flora Advisory Committee 1994: Native higher plant taxa which are rare or threatened in Tasmania. Edition 1 Species at Risk, Tasmania. Parks and Wildlife Service, Tasmania, Hobart: 23 pp.

Grant, J., Laffan, M., Hill, R. \& Neilsen, W. 1995: Forest Soils of Tasmania. Forestry Tasmania, Hobart: $189 \mathrm{pp}$.

Harden, G.J. \& Everett, J. 1990: Dilleniaceae. 293-303, In Harden, G.J. (ed): Flora of New South Wales. University of New South Wales Press Ltd, Sydney: 574 pp.

Hopkins, K. 1995: The Distribution of Hibbertia calycina (Guinea Flower) in the St Helens - Scamander Area. Report to the Eastern Tiers District. Forestry Tasmania: Hobart: $44 \mathrm{pp}$.

Kitchener, A. \& Harris, S. 2013: From Forest to Fjaeldmark: Descriptions of Tasmania's Vegetation. Edition 2. Department of Primary Industries, Parks, Water and Environment, Tasmania: 24 pp.

Legge, S., Lindenmayer, D., Robinson, N., Schelle, B., Southwell, D. \& Wintle, B. 2018: Monitoring threatened species and ecological communities. CSIRO Publishing, Australia: $480 \mathrm{pp}$.

Neyland, M. \& Askey-Doran, M. 1996: Effects of repeated fires on dry sclerophyll ( $E$ sieberi) forests in northeast Tasmania. Records of the Queen Victoria Museum and Art Gallery 103: 47-50.

Podger, F.D., Mummery, D.C., Palzer, C.R. \& Brown, M.J. 1990: Bioclimatic analysis of the distribution of damage to native plants in Tasmania by Phytophthora cinnamomi. Australian Journal of Ecology 15: 281-289.

Pyrke, A.F. \& Marsden-Smedley, J.B. 2005: Fire-attributes categories, fire sensitivity, and flammability of Tasmanian vegetation communities. Tasforests 16: 35-46.

R Core Team. 2019: R: A language and environment for statistical computing. R Foundation for Statistical Computing, Vienna, Austria. www.R-project.org/.

Reiter, N., Weste, G. \& Guest, D. 2004: The risk of extinction resulting from disease caused by Phytophthora cinnamomi to endangered, vulnerable or rare plant species endemic to the Grampians, western Victoria. Australian Journal of Botany 52: 425-433.
Ribeiro O.K. 1978: A source book of the genus Phytophthora. Strauss and Cramer, Vaduz, Germany: $417 \mathrm{pp}$.

Schahinger, R., Rudman, T. \& Wardlaw, T.J. 2003: Conservation of Tasmanian plant species and communities threatened by Phytophthora cinnamomi. Strategic Regional Plan for Tasmania Technical Report 03/03. Nature Conservation Branch, Department of Primary Industries, Water and Environment: Hobart. https://dpipwe.tas.gov. $\mathrm{au} /$ Documents/Conservation-of-Tas-Plant-SpeciesThreatened-by-Phytophthora.pdf (accessed 7 May 2019).

Schatral, A., Osborne, J.M. \& Fox, J.E.D. 1997: Dormancy in seeds of Hibbertia cuneiformis and H. huegelii (Dilleniaceae). Australian Journal of Botany 45: 1045-1053.

Silcock, J.L. \& Fensham, R.J. 2018: Using evidence of decline and extinction risk to identify priority regions, habitats and threats for plant conservation in Australia. Australian Journal of Botany 66: 541-555.

Tasmanian Government 2017: LISTmap - Land Information System of Tasmania. Tasmanian Government: Hobart: http:// maps.thelist.tas.gov.au/listmap/app/list/map (accessed 7 May 2019)

Threatened Species Section 2020: Mirbelia oxylobioides (sandstone bushpea): Species Management Profile for Tasmania's Threatened Species Link. www.threatenedspecieslink.tas. gov.au/Pages/Mirbelia-oxylobioides.aspx. Department of Primary Industries, Parks, Water and Environment, Tasmania (accessed 10 October 2020).

Toelken, H.R. 1996: Hibbertia. In Walsh, N.G. \& Entwisle, T.J. (eds): Flora of Victoria Volume 3 Dicotyledons Winteraceae to Myrtaceae. Inkata Press, Melbourne: 300-313. https:// vicflora.rbg.vic.gov.au/flora/key/2245

Tolsma, A., Brown, G. \& Cheal, D. 2010: The likely impacts of prescribed fire on the flora and fauna of box-ironbark remnants. Transactions of the Royal Society of Victoria 122: lxxxv-xc.

Weste, G. \& Ashton, D.H. 1994: Regeneration and survival of indigenous dry sclerophyll species in the Brisbane Ranges, Victoria, after a Phytophthora cinnamomi epidemic. Australian Journal of Botany 42: 239-253.

Wickham, H. 2016: ggplot2: Elegant Graphics for Data Analysis. Springer-Verlag, New York: 216 pp.

Wickham, H., François, R., Henry, L. \& Müller, K. 2020: dplyr: A Grammar of Data Manipulation. R package version 1.0.0. https://CRAN.R-project.org/package=dplyr

(accepted 12 October 2020) 


\section{APPENDIX 1}

\section{History of Hibbertia calycina collections in Tasmania}

\section{Background}

Hibbertia Andrews is a genus of more than 170 species, distributed mainly in Australia and extending to New Guinea, Madagascar and some Pacific islands (APNI 2019). The number of species recognised in Tasmania has been somewhat fluid, especially in recent years as the taxonomy of some of the species complexes of southeastern Australia are resolved (e.g., Toelken 1998, 2000, 2013). Tasmania currently has eighteen accepted species of Hibbertia (de Salas \& Baker 2019). One species, $H$. basaltica, is recognised as endemic to the state (Buchanan $\&$ Schahinger 2000). Some of the nonendemic species have localised distributions in Tasmania. In Tasmania, they include H. calycina (DC.) N.A.Wakef. (de Salas \& Baker 2019), which also occurs in Victoria (Willis 1972, Toelken 1996), New South Wales (Harden \& Everett 1990), and the Australian Capital Territory (Burbidge \& Gray 1970). The recognition in other state floras that ' $H$. calycina' also occurred in Tasmania is a relatively recent development. For example, Toelken (1996) in the Flora of Victoria's treatment of Hibbertia did not attribute the species to Tasmania, although the current online version now does.

\section{In Tasmania}

Hibbertia calycina (plate 1 in the main article) was not included in The Student's Flora of Tasmania Part 1 (Curtis \& Morris 1975), since the Tasmanian Herbarium did not hold any specimens attributable to the species until the early 1980 s. That such a distinctive species was apparently overlooked (or at least not collected) for close to two centuries of European occupation is somewhat surprising, especially given focus on the flora of the greater St Helens region in the late 1800s. In 1892 Fitzgerald collected $H$. rufa N.A. Wakef. from the area; this species was not recorded again until 2008, when it was found to be localised but often abundant (Wapstra et al. 2011) in heathland north of St Helens. Elsewhere, two species of Hibbertia, both distributed around Sydney, also went overlooked, despite 200 years of occupation: $H$. spanantha Toelken \& A.F.Rob. is a newly-described species known from three populations totalling 20 plants and listed as Critically Endangered (New South Wales Threatened Species Conservation Act 1995, Toelken \& Robinson 2015); $H$. fumana Sieber ex Toelken has been recently rediscovered: with a population of 370 plants it is provisionally listed as Critically Endangered (New South Wales Threatened Species Conservation Act 1995, Duretto et al. 2017).

Prior to the recent submission of a batch of voucher specimens from surveys conducted in 2003/2004 (MW), the Tasmanian Herbarium only held eight sheets of Hibbertia calycina, the earliest from 9 Oct. 1980, three from 15 Jun. 1981, one from 8 Aug. 1981, and one each from 19 Oct. 1993, 6 Apr. 1995 and 20 Sep. 1999. The specimens from 1981 were originally labelled "Hibbertia ?cistiflora", presumably reflecting the use of a mainland flora to identify the specimens (A. Buchanan pers. comm.), but all subsequent specimens were labelled as 'Hibbertia calycina'. The Queen Victoria Museum and Art Gallery (QVMAG) also holds five collections of the taxon, two of which are apparent duplicates (both labelled "Upper Scamander Pitts Hill”, dated 9 Oct. 1980, and attributed to Mary Cameron), these probably being duplicates of the specimen held at the Tasmanian Herbarium with the same date and location. Of note is that these specimens are labelled "first recording for Tasmania". Other collections held at QVMAG include two from 20 Aug. 1981, attributed to "Forestry Officers" and one from 29 Sep. 1987 (also a Mary Cameron collection).

\section{References}

APNI (Australian Plant Name Index) 2019: IBIS database, Centre for Australian National Biodiversity Research, Australian Government, Canberra. www.cpbr.gov.au/cgi-bin/apni (accessed 7 May 2019).

Buchanan, A.M. \& Schahinger, R.B. 2005: A new endemic species of Hibbertia (Dilleniaceae) from Tasmania. Muelleria $\mathbf{2 2}$ 105-109.

Burbidge, N.T. \& Gray, M. 1970: Flora of the Australian Capital Territory. Australian National University Press, Canberra: $447 \mathrm{pp}$.

Curtis, W.M. \& Morris, D.I. 1975: The Student's Flora of Tasmania Part 1 Gymnospermae, Angiospermae: Ranunculaceae to Myrtaceae (Second Edition, 1981 Reprint). Government Printer, Hobart: 240 pp.

de Salas, M.F. \& Baker, M.L. 2019: A Census of the Vascular Plants of Tasmania, including Macquarie Island. Tasmanian Herbarium, Tasmanian Museum and Art Gallery, Hobart: 156 pp. www.tmag.tas.gov.au/__data/assets/ pdf_file/0005/179915/2018_Census_of_Tasmanian_ Vascular_Plants.pdf (accessed 7 May 2019).

Duretto, M.F., Orme, A.E, Rodd, J., Stables, M. \& Toelken, H. 2017: Hibbertia fumana (Dilleniaceae), a species presumed to be extinct rediscovered in the Sydney region, Australia. Telopea 20: 143-146.

Harden, G.J. \& Everett, J. 1990: Dilleniaceae. In Harden, G.J. (ed.): Flora of New South Wales. University of New South Wales Press Ltd: Sydney: 293-303. https://profiles.ala.org. au/opus/foa/profile/Dilleniaceae

Toelken, H.R. 1996: Hibbertia. In Walsh, N.G. \& Entwisle, T.J. (eds): Flora of Victoria Volume 3 Dicotyledons Winteraceae to Myrtaceae. Inkata Press, Melbourne: 300-313. https:// vicflora.rbg.vic.gov.au/flora/key/2245

Toelken, H.R. 1998: Notes on Hibbertia (Dilleniaceae) 2. The $H$ aspera- $H$ empetrifolia complex. Journal of the Adelaide Botanic Gardens 18(2): 107-160.

Toelken, H.R. 2000: Notes on Hibbertia (Dilleniaceae) 3. H sericea and associated species. Journal of the Adelaide Botanic Gardens 19: 1-54.

Toelken, H.R. 2013: Notes on Hibbertia subg Hemistemma (Dilleniaceae) 9. The eastern Australian $H$ vestita group, including $H$ pedunculata and $H$ serpyllifolia. Journal of the Adelaide Botanic Gardens 26: 31-69.

Toelken, H.R. \& Robinson, A.F. 2015: Notes on Hibbertia (Dilleniaceae) 11. Hibbertia spanantha, a new species from the central coast of New South Wales. Journal of the Adelaide Botanic Gardens 29: 11-14.

Wapstra, M., French, B., Tyquin, V. \& Skabo, R. 2011: From presumed extinct to probably secure? The resurrection and ongoing management of Hibbertia rufa (brown guineaflower) in north-east Tasmania. Tasforests 19: 54-70.

Willis, J.H. 1972: A Handbook to Plants in Victoria, Volume II, Dicotyledons. Melbourne University Press, Melbourne: 832. 


\section{APPENDIX 2}

Clumps of Hibbertia calycina in northeastern Tasmania.

Clump numbers for 2017/18 and 1995 surveys are shown. (a) Mt Echo, (b) Loila Pinnacle/Wolfram, (c) Pyramid, (d) Oreico, (e) Skyline, (f) McIntyres East and McIntyres West, (g) Bolpeys, (h) Flagstaff, (i) Basin Creek. Inset: Map of Tasmania showing position of all clumps.

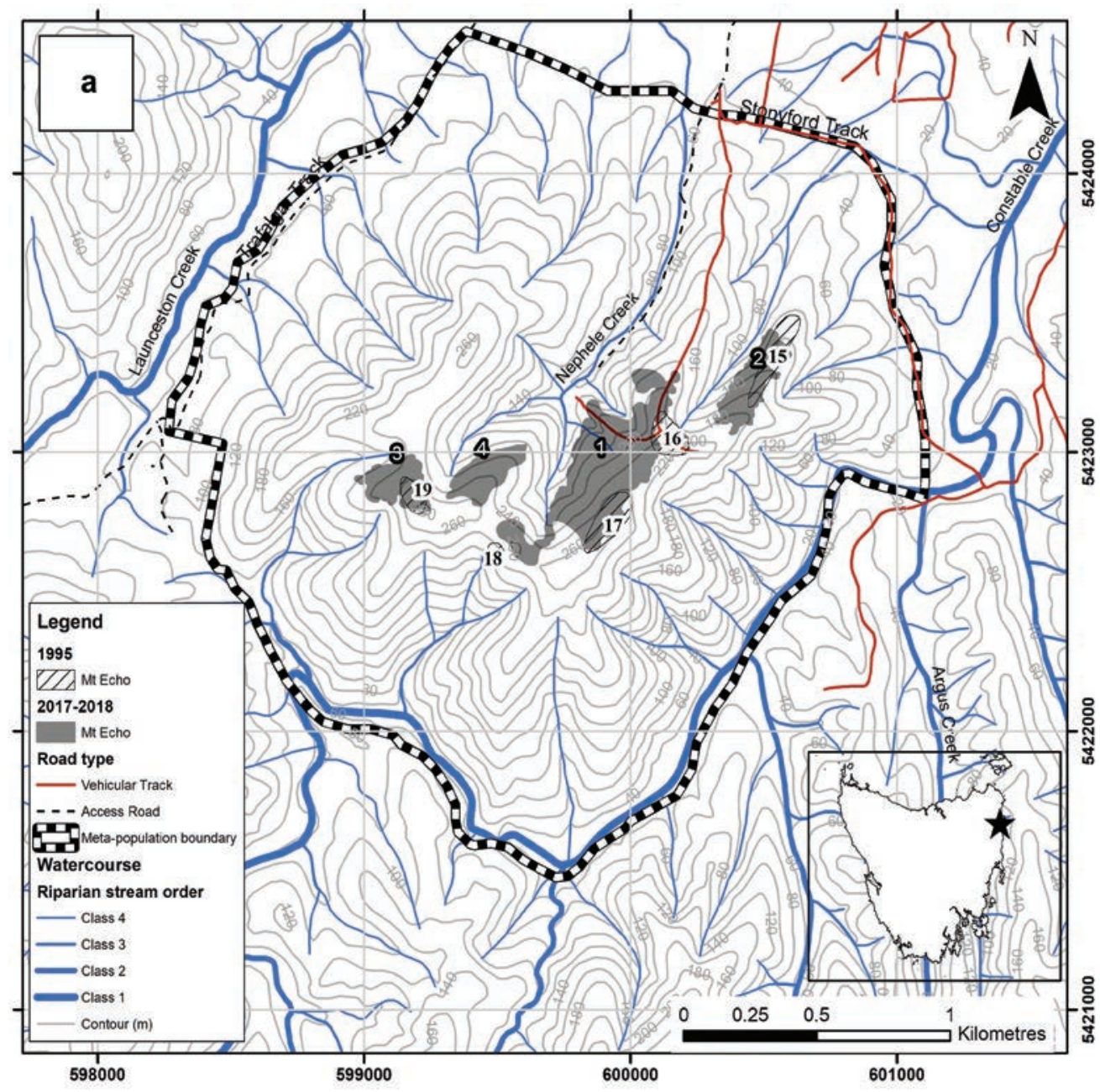


74 Perpetua A.M. Turner, Mark Wapstra, Allison Woolley, Katriona Hopkins, Amelia J. Koch and Fred Duncan APPENDIX 2 - cont.
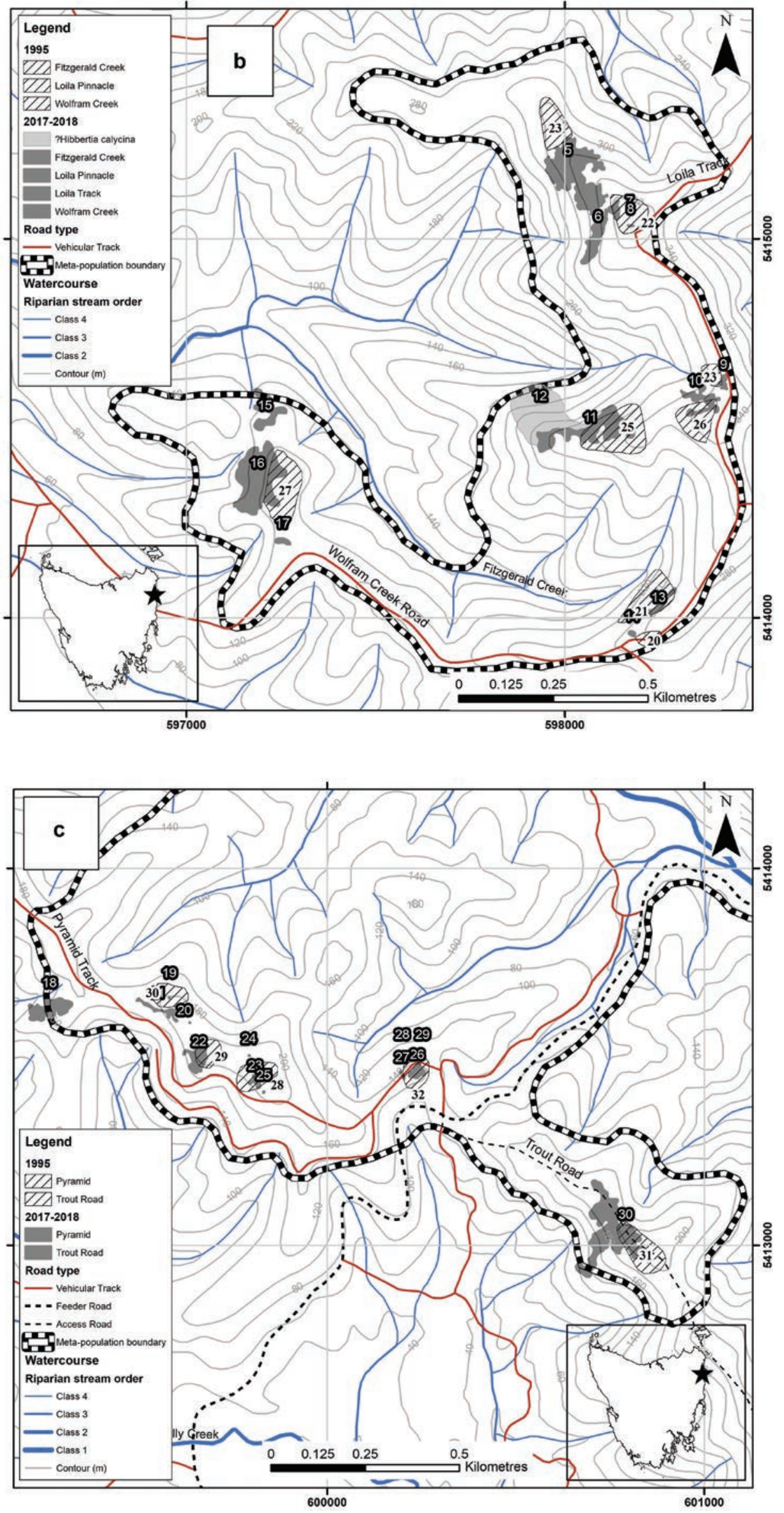
APPENDIX 2 - cont.
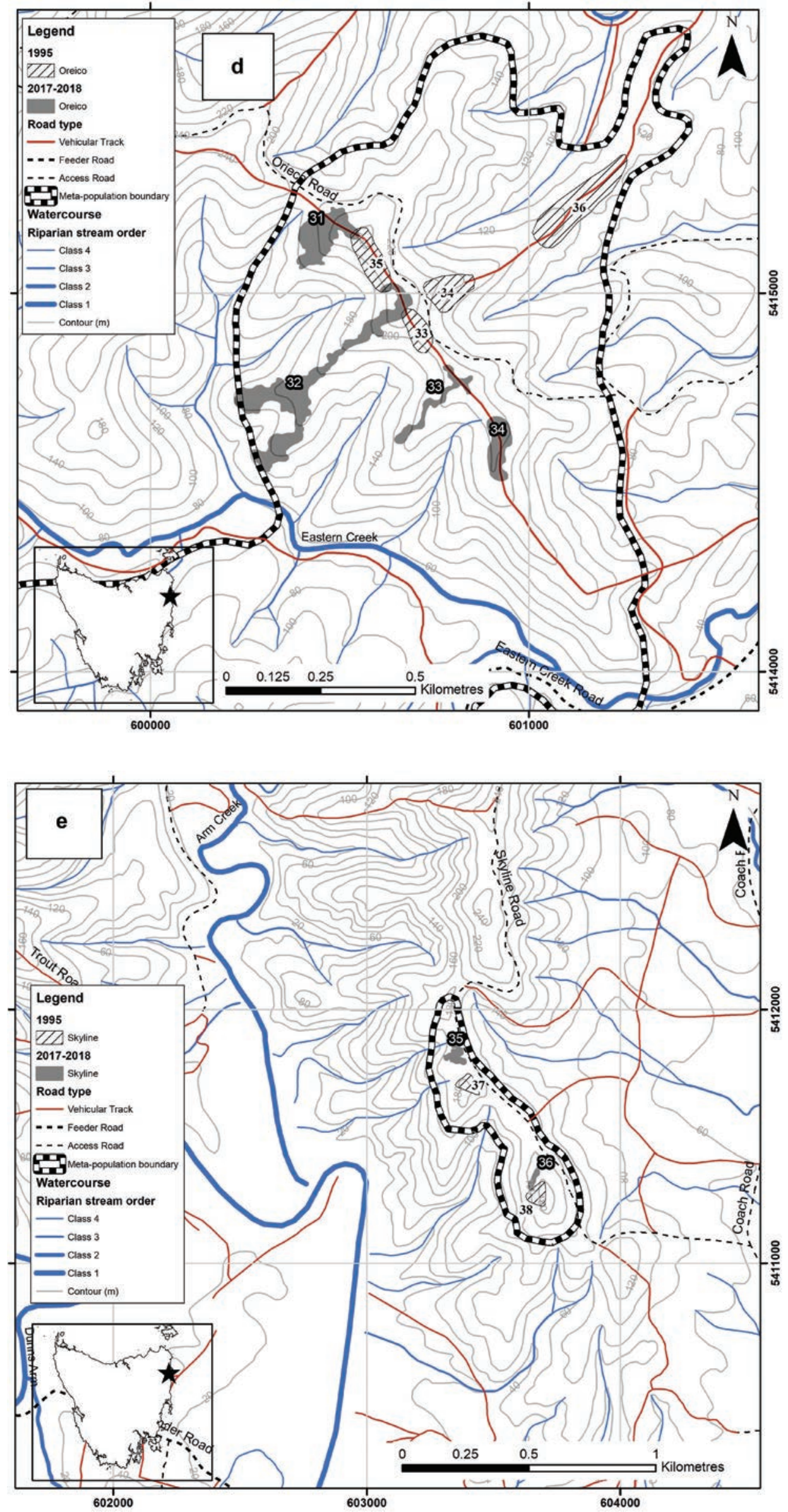
APPENDIX 2 - cont.
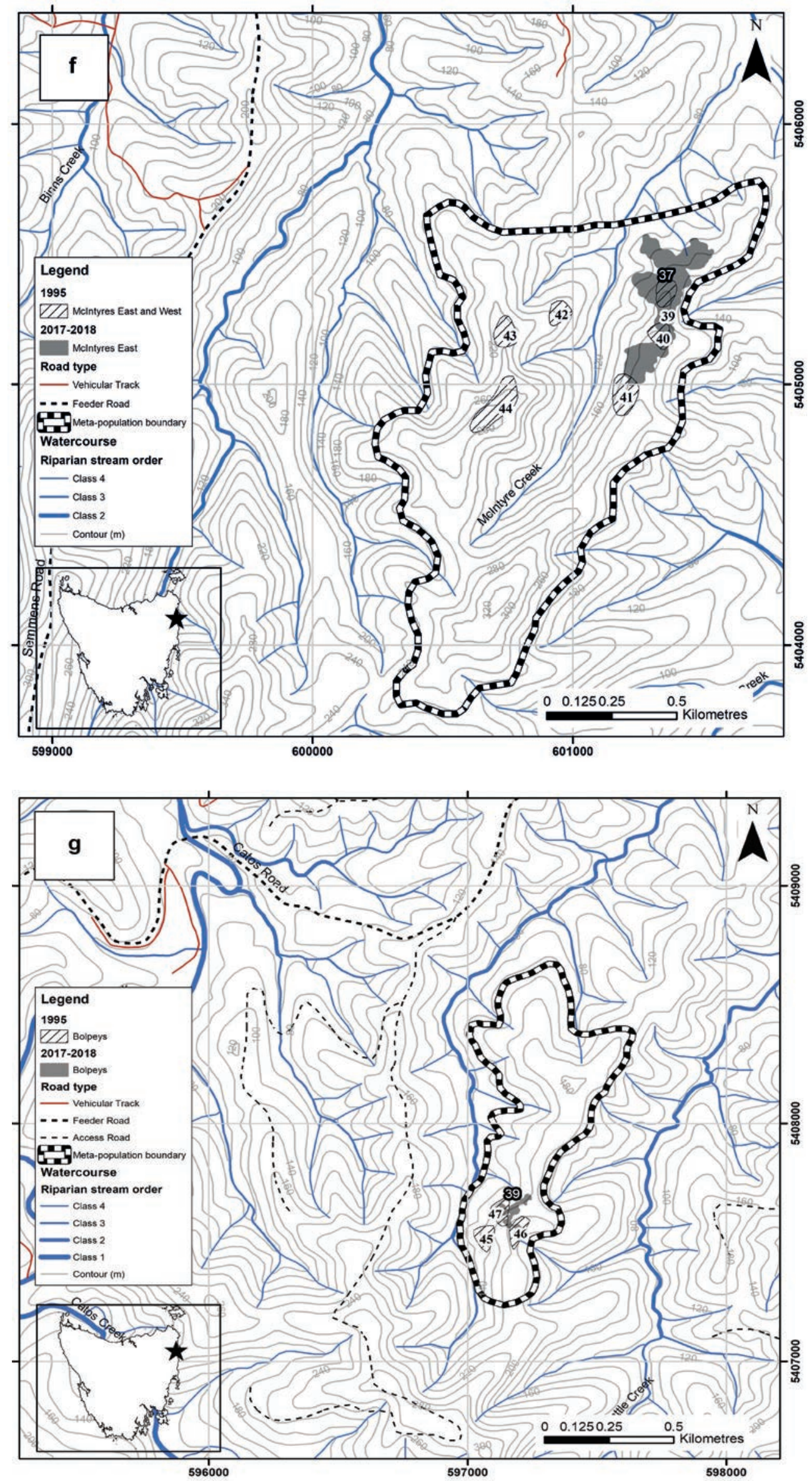
APPENDIX 2 - cont.
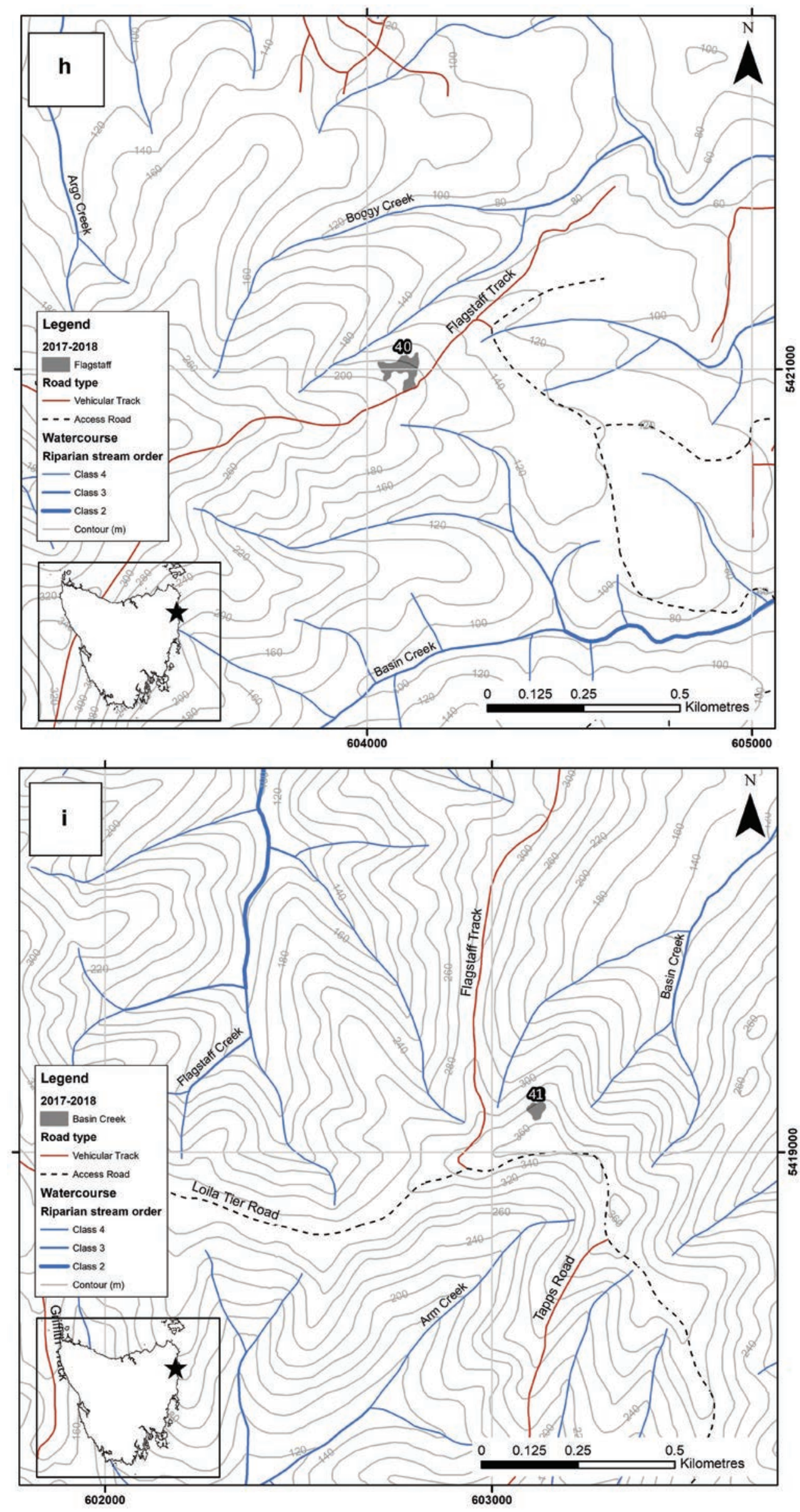


\section{APPENDIX 3}

Mean height of $H$. calycina $(\mathrm{cm})( \pm 95 \% \mathrm{CI})$, from a random subset of clumps during the 2017/2018 survey, plotted against the most recent fire event (year). Clumps were selected based on 1995 survey clump numbers; labels are the 2017/2018 clump number. See Appendix 4 for details.

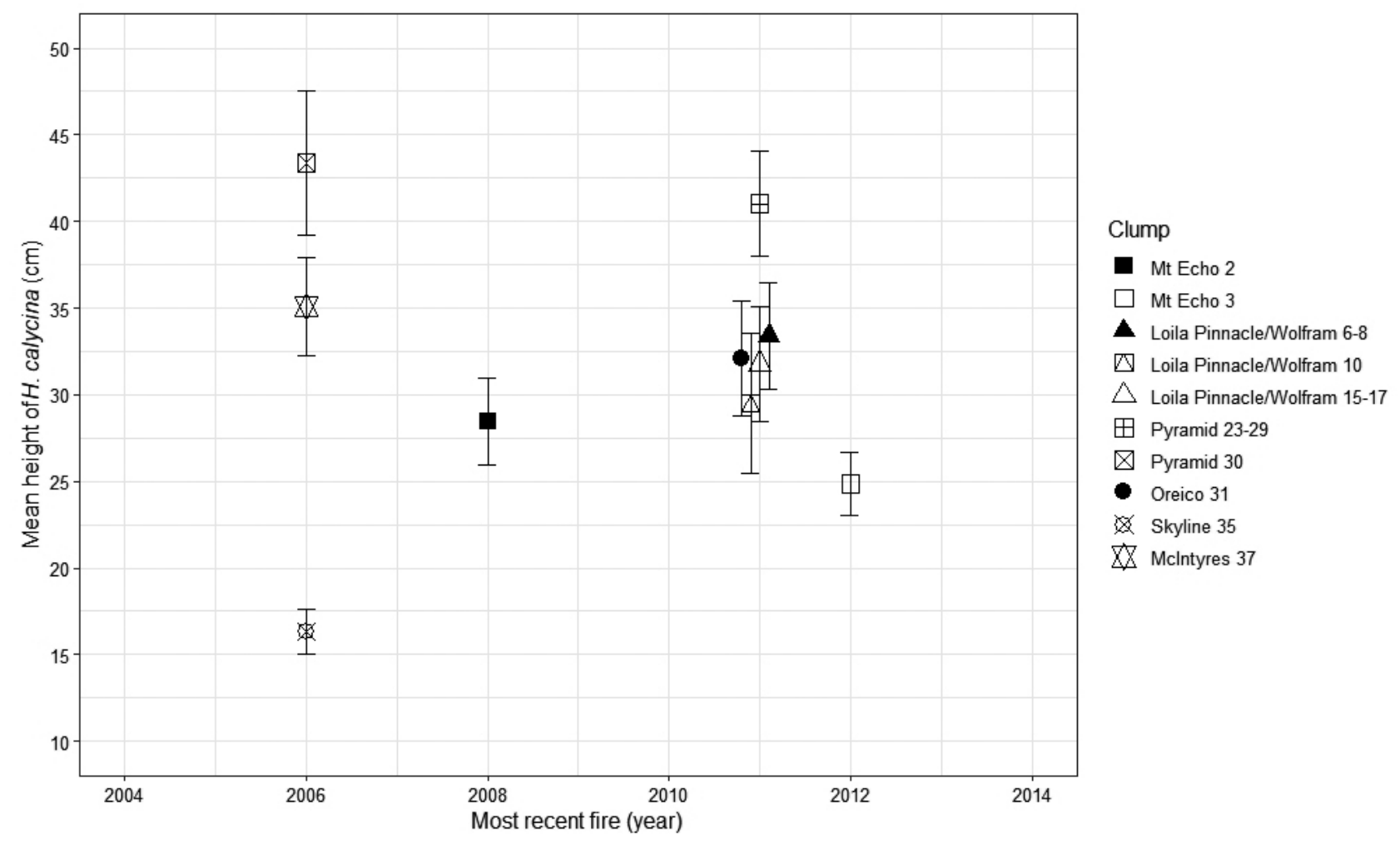




\section{APPENDIX 4}

Environmental and historical information for clumps of Hibbertia calycina in northeastern Tasmania.

\begin{tabular}{|c|c|c|c|c|c|c|c|}
\hline \multicolumn{8}{|l|}{ RIDGELINE } \\
\hline \multirow{2}{*}{$\begin{array}{l}\text { Tenure: } 1995 \text { and } \\
2018\end{array}$} & \multicolumn{2}{|c|}{ Clump no } & Clump location & \multirow[t]{2}{*}{ Landform } & \multirow{2}{*}{$\begin{array}{l}\text { Fire events } \\
\text { (month/year) }\end{array}$} & \multirow[t]{2}{*}{ Aspect } & \multirow{2}{*}{$\begin{array}{l}\text { Elevation } \\
\quad(\mathrm{m})\end{array}$} \\
\hline & 1995 & $2017 / 2018$ & $2017 / 2018$ & & & & \\
\hline \multirow{4}{*}{$\begin{array}{l}\text { Mt Echo } \\
\text { 1995: State Forest } \\
\text { (production). } \\
\text { 2018: Future } \\
\text { Potential Production } \\
\text { Forest }\end{array}$} & $16,17,18$ & 1 & $\begin{array}{l}\text { Mt Echo ridgeline road and } \\
\text { northeast above Nephele } \\
\text { Creek }\end{array}$ & $\begin{array}{l}\text { ridge and } \\
\text { mid-slope }\end{array}$ & $\begin{array}{l}1985-87 \text { (frb), } \\
10 / 1994 \text { (wild), } \\
10 / 2008 \text { (frb), } \\
10 / 2012 \text { (frb) }\end{array}$ & $\begin{array}{l}\text { E, NE, } \\
\text { N, NW }\end{array}$ & $130-200$ \\
\hline & 15 & 2 & $\begin{array}{l}\text { Mt Echo, northeast } \\
\text { catchment of Constable } \\
\text { Creek }\end{array}$ & $\begin{array}{l}\text { ridge and } \\
\text { mid-slope }\end{array}$ & $\begin{array}{l}11 / 2003 \text { (unk), } \\
10 / 2008 \text { (frb) }\end{array}$ & $\mathrm{N}, \mathrm{NE}$ & $100-190$ \\
\hline & 19 & 3 & Mt Echo, northwest ridge & $\begin{array}{l}\text { ridge and } \\
\text { mid-slope }\end{array}$ & $\begin{array}{l}10 / 2008 \text { (frb), } \\
10 / 2012 \text { (frb) }\end{array}$ & NW & $220-280$ \\
\hline & 19 & 4 & $\begin{array}{l}\text { Mt Echo, east of northwest } \\
\text { ridge }\end{array}$ & $\begin{array}{l}\text { ridge and } \\
\text { mid-slope }\end{array}$ & $10 / 2008$ (frb) & $\mathrm{NE}$ & $200-260$ \\
\hline \multirow{12}{*}{$\begin{array}{l}\text { Loila Pinnacle/ } \\
\text { Wolfram } \\
\text { 1995: State Forest } \\
\text { (production). } \\
\text { 2018: Future } \\
\text { Potential Production } \\
\text { Forest }\end{array}$} & 23 & 5 & Loila Pinnacle & ridge & $\begin{array}{l}\text { 1987-88 (unk), } \\
10 / 2011 \text { (frb) }\end{array}$ & W, NW & $280-350$ \\
\hline & 22 & 6 & Loila Pinnacle & ridge & $\begin{array}{l}\text { 1987-88 (unk), } \\
10 / 2011 \text { (frb) }\end{array}$ & W, NW & $310-370$ \\
\hline & 22 & 7,8 & Loila Pinnacle & ridge & $\begin{array}{l}1987-88 \text { (unk), } \\
10 / 2011 \text { (frb) }\end{array}$ & $\mathrm{N}$ & 370 \\
\hline & 24 & 9 & $\begin{array}{l}\text { Immediately west of Loila } \\
\text { Track (headwaters of } \\
\text { Fitzgerald Creek) }\end{array}$ & hilltop & $10 / 2011(\mathrm{frb})$ & $\mathrm{N}$ & $340-350$ \\
\hline & 26 & 10 & $\begin{array}{l}\text { Immediately west of Loila } \\
\text { Track (headwaters of } \\
\text { Fitzgerald Creek) }\end{array}$ & hilltop & $10 / 2011$ (frb) & W, NW & $320-350$ \\
\hline & 25 & 11 & $\begin{array}{l}\text { Ridge west of Loila Track } \\
\text { (catchment of Fitzgerald } \\
\text { Creek) }\end{array}$ & hilltop & $10 / 2011$ (frb) & NW, W & $270-320$ \\
\hline & 25 & 12 & $\begin{array}{l}\text { Ridge west of Loila Track } \\
\text { (catchment of Fitzgerald } \\
\text { Creek) }\end{array}$ & hilltop & $10 / 2011$ (frb) & $\mathrm{N}$ & $190-300$ \\
\hline & 21 & 13 & $\begin{array}{l}\text { Northeast of junction of } \\
\text { Loila Track and Wolfram } \\
\text { Creek Track }\end{array}$ & $\begin{array}{l}\text { ridge and } \\
\text { mid-slope }\end{array}$ & $10 / 2011$ (frb) & W & $250-260$ \\
\hline & 20 & 14 & $\begin{array}{l}\text { North of junction of Loila } \\
\text { Track and Wolfram Creek } \\
\text { Track }\end{array}$ & $\begin{array}{l}\text { ridge and } \\
\text { mid-slope }\end{array}$ & $10 / 2011$ (frb) & W & $240-250$ \\
\hline & 27 & 15 & $\begin{array}{l}\text { north of Wolfram Creek } \\
\text { Track, catchment of } \\
\text { Fitzgerald Creek }\end{array}$ & $\begin{array}{l}\text { ridge and } \\
\text { mid-upper } \\
\text { slope }\end{array}$ & $\begin{array}{l}1987-88 \text { (unk), } \\
10 / 2011 \text { (frb) }\end{array}$ & $\mathrm{N}$ & $120-150$ \\
\hline & 27 & 16 & $\begin{array}{l}\text { north of Wolfram Creek } \\
\text { Track, catchment of } \\
\text { Fitzgerald Creek }\end{array}$ & $\begin{array}{l}\text { ridge and } \\
\text { mid-upper } \\
\text { slope }\end{array}$ & $\begin{array}{l}\text { 1987-88 (unk), } \\
10 / 2011 \text { (frb) }\end{array}$ & W & $130-170$ \\
\hline & 27 & 17 & $\begin{array}{l}\text { north of Wolfram Creek } \\
\text { Track, catchment of } \\
\text { Fitzgerald Creek }\end{array}$ & $\begin{array}{l}\text { ridge and } \\
\text { mid-upper } \\
\text { slope }\end{array}$ & $\begin{array}{l}\text { 1987-88 (unk), } \\
10 / 2011 \text { (frb) }\end{array}$ & W & $160-170$ \\
\hline
\end{tabular}


APPENDIX 4 - cont.

\begin{tabular}{|c|c|c|c|c|c|c|c|}
\hline \multirow{2}{*}{$\begin{array}{l}\text { Tenure: } 1995 \text { and } \\
2018\end{array}$} & \multicolumn{2}{|c|}{ Clump no } & \multirow{2}{*}{$\begin{array}{c}\text { Clump location } \\
2017 / 2018\end{array}$} & \multirow[t]{2}{*}{ Landform } & \multirow{2}{*}{$\begin{array}{l}\text { Fire events } \\
\text { (month/year) }\end{array}$} & \multirow[t]{2}{*}{ Aspect } & \multirow{2}{*}{$\begin{array}{l}\text { Elevation } \\
(\mathrm{m})\end{array}$} \\
\hline & 1995 & $2017 / 2018$ & & & & & \\
\hline \multirow{11}{*}{$\begin{array}{l}\text { Pyramid } \\
\text { 1995: State Forest } \\
\text { (production). } \\
\text { 2018: Future } \\
\text { Potential Production } \\
\text { Forest }\end{array}$} & NA & 18 & $\begin{array}{l}\text { southwest of Pyramid Track, } \\
\text { catchment of Kelly Creek }\end{array}$ & $\begin{array}{l}\text { hilltop/ } \\
\text { sides of } \\
\text { slope }\end{array}$ & $\begin{array}{l}\text { 1984-85 (frb), } \\
10 / 2011(\text { frb) }\end{array}$ & W & $140-170$ \\
\hline & 30 & 19 & $\begin{array}{l}\text { Pyramid Hill (continuation } \\
\text { of ridge to northwest of main } \\
\text { hill) }\end{array}$ & $\begin{array}{l}\text { hilltop/ } \\
\text { sides of } \\
\text { slope }\end{array}$ & $10 / 2011$ (frb) & NW & 180 \\
\hline & 30 & 20 & $\begin{array}{l}\text { Pyramid Hill (continuation } \\
\text { of ridge to northwest of main } \\
\text { hill) }\end{array}$ & $\begin{array}{l}\text { hilltop/ } \\
\text { sides of } \\
\text { slope }\end{array}$ & $10 / 2011(\mathrm{frb})$ & NW & 190 \\
\hline & 30 & 21 & $\begin{array}{l}\text { Pyramid Hill (continuation } \\
\text { of ridge to northwest of main } \\
\text { hill) }\end{array}$ & $\begin{array}{l}\text { hilltop/ } \\
\text { sides of } \\
\text { slope }\end{array}$ & $10 / 2011$ (frb) & W & $170-190$ \\
\hline & 29 & 22 & $\begin{array}{l}\text { Pyramid Hill (continuation } \\
\text { of ridge to northwest of main } \\
\text { hill) }\end{array}$ & $\begin{array}{l}\text { hilltop/ } \\
\text { sides of } \\
\text { slope }\end{array}$ & $10 / 2011$ (frb) & NW & $170-190$ \\
\hline & 28 & 23 & Pyramid Hill & $\begin{array}{l}\text { hilltop/ } \\
\text { sides of } \\
\text { slope }\end{array}$ & $10 / 2011$ (frb) & W & $200-220$ \\
\hline & 28 & 24 & Pyramid Hill & $\begin{array}{l}\text { hilltop/ } \\
\text { sides of } \\
\text { slope }\end{array}$ & $10 / 2011(\mathrm{frb})$ & $\mathrm{N}$ & 210 \\
\hline & 28 & 25 & Pyramid Hill & $\begin{array}{l}\text { hilltop/ } \\
\text { sides of } \\
\text { slope }\end{array}$ & $10 / 2011(\mathrm{frb})$ & W & 210 \\
\hline & 32 & 26,27 & $\begin{array}{l}\text { Pyramid Track, east of } \\
\text { Pyramid Hill, just west of } \\
\text { junction with Eastern Creek } \\
\text { Road }\end{array}$ & ridge & $10 / 2011(\mathrm{frb})$ & $\mathrm{N}$ & 140 \\
\hline & 32 & 28,29 & $\begin{array}{l}\text { Pyramid Track, east of } \\
\text { Pyramid Hill, just west of } \\
\text { junction with Eastern Creek } \\
\text { Road }\end{array}$ & ridge & $10 / 2011(\mathrm{frb})$ & $\mathrm{N}$ & 130 \\
\hline & 31 & 30 & $\begin{array}{l}\text { Trout Road, northwest of } \\
\text { Pitts Hill }\end{array}$ & ridge & $\begin{array}{l}1983 \text { (unk), } \\
08 / 2006 \text { (frb; } \\
\text { northeast side of } \\
\text { road only) }\end{array}$ & $\begin{array}{l}\text { NW, } \\
\text { SW }\end{array}$ & $120-210$ \\
\hline \multirow[t]{5}{*}{$\begin{array}{l}\text { Oreico } \\
\text { 1995: State Forest } \\
\text { (production). } \\
\text { 2018: Future } \\
\text { Potential Production } \\
\text { Forest }\end{array}$} & 35 & 31 & $\begin{array}{l}\text { northwest of Orieco Hill, } \\
\text { southwest of Orieco Road, } \\
\text { catchment of Eastern Creek }\end{array}$ & ridge & $\begin{array}{l}1984-85 \\
\text { (unk), 10/2011 } \\
\text { (frb) (extinct } \\
\text { northeast } \\
\text { population [No } \\
36 \text { in } 1995 \text { ] was } \\
\text { last burnt in } \\
10 / 2012 \text { (frb)) }\end{array}$ & $\begin{array}{l}\text { NW, } \\
\text { SW }\end{array}$ & $180-240$ \\
\hline & 36 & extinct & Orieco Hill, & $\begin{array}{l}\text { mid-upper } \\
\text { slope }\end{array}$ & & NE & $110-130$ \\
\hline & 34 & 32 & $\begin{array}{l}\text { Orieco Hill, Oreico Hill top, } \\
\text { Oreico Hill south east }\end{array}$ & ridge & $10 / 2011(\mathrm{frb})$ & W, SW & $100-230$ \\
\hline & 33 & 33 & $\begin{array}{l}\text { Orieco Hill, Oreico Hill top, } \\
\text { Oreico Hill south east }\end{array}$ & ridge & $10 / 2011(\mathrm{frb})$ & W, SW & $160-210$ \\
\hline & 33 & 34 & $\begin{array}{l}\text { Orieco Hill, Oreico Hill top, } \\
\text { Oreico Hill south east }\end{array}$ & ridge & $10 / 2011$ (frb) & W, S & $190-200$ \\
\hline
\end{tabular}


APPENDIX 4 - cont.

\begin{tabular}{|c|c|c|c|c|c|c|c|}
\hline \multirow{2}{*}{$\begin{array}{l}\text { Tenure: } 1995 \text { and } \\
2018\end{array}$} & \multicolumn{2}{|c|}{ Clump no } & \multirow{2}{*}{$\begin{array}{c}\text { Clump location } \\
2017 / 2018\end{array}$} & \multirow[t]{2}{*}{ Landform } & \multirow{2}{*}{$\begin{array}{l}\text { Fire events } \\
\text { (month/year) }\end{array}$} & \multirow[t]{2}{*}{ Aspect } & \multirow{2}{*}{$\begin{array}{l}\text { Elevation } \\
\quad(\mathrm{m})\end{array}$} \\
\hline & 1995 & $2017 / 2018$ & & & & & \\
\hline \multirow{2}{*}{$\begin{array}{l}\text { Skyline } \\
\text { 1995: Scamander } \\
\text { Forest Reserve } \\
\text { (transferred to Parks } \\
\text { and Wildlife Service } \\
\text { from Forestry } \\
\text { Tasmania). } \\
\text { 2018: Scamander } \\
\text { Regional Reserve }\end{array}$} & 37 & 35 & $\begin{array}{l}\text { Skyline Tier (near southern } \\
\text { end and far southern end) }\end{array}$ & ridge & $\begin{array}{l}10 / 1993 \text { (cool } \\
\text { burn), } 12 / 2006 \\
\text { (esc) }\end{array}$ & W, NW & $170-180$ \\
\hline & 38 & 36 & $\begin{array}{l}\text { Skyline Tier (near southern } \\
\text { end and far southern end) }\end{array}$ & ridge & $\begin{array}{l}10 / 1993 \text { (cool } \\
\text { burn), } 12 / 2006 \\
\text { (esc) }\end{array}$ & W, NW & $160-170$ \\
\hline $\begin{array}{l}\text { McIntyres (East) } \\
\text { 1995: State Forest } \\
\text { (production) } \\
\text { 2018: Ridgeline } \\
\text { is the boundary } \\
\text { between Future } \\
\text { Potential Production } \\
\text { Forest (east of } \\
\text { ridge so the smaller } \\
\text { part of the sub- } \\
\text { population) and } \\
\text { the German Town } \\
\text { Regional Reserve } \\
\text { (west of the ridge so } \\
\text { the greater part of } \\
\text { the population) }\end{array}$ & $\begin{array}{l}39,40 \\
41\end{array}$ & 37 & McIntyres Ridge (East) & $\begin{array}{l}\text { ridge and } \\
\text { steep sides }\end{array}$ & $12 / 2006$ (esc) & W, NW & $150-200$ \\
\hline $\begin{array}{l}\text { McIntyres (West) } \\
\text { 1995: German } \\
\text { Town Forest Reserve } \\
\text { (transferred to Parks } \\
\text { and Wildlife Service } \\
\text { from Forestry } \\
\text { Tasmania) } \\
\text { 2018: German } \\
\text { Town Regional } \\
\text { Reserve }\end{array}$ & $\begin{array}{l}42,43 \\
\quad 44\end{array}$ & 38 & McIntyres Ridge (West) & $\begin{array}{l}\text { ridge and } \\
\text { steep sides }\end{array}$ & $\begin{array}{l}1976-77 \\
\text { (unk; dated } \\
\text { from Banksia } \\
\text { regrowth), } \\
12 / 2006 \text { (esc) }\end{array}$ & NW, N & $160-290$ \\
\hline $\begin{array}{l}\text { Bolpeys } \\
\text { 1995: State Forest } \\
\text { (production) } \\
\text { 2018: Permanent } \\
\text { Timber Production } \\
\text { Zone land }\end{array}$ & $\begin{array}{l}45,46 \\
47\end{array}$ & 39 & $\begin{array}{l}\text { between Bolpeys Ridge and } \\
\text { Catos Road (catchment of } \\
\text { Wattle Creek) }\end{array}$ & ridge & $12 / 2006$ (esc) & W, NW & $140-180$ \\
\hline $\begin{array}{l}\text { Flagstaff } \\
\text { 1995: State Forest } \\
\text { (production) } \\
\text { 2018: Future } \\
\text { Potential Production } \\
\text { Forest }\end{array}$ & - & 40 & $\begin{array}{l}\text { between Flagstaff Track and } \\
\text { Boggy Creek c. } 500 \text { m ENE } \\
\text { Flagstaff Lookout }\end{array}$ & $\begin{array}{l}\text { mid-upper } \\
\text { slope }\end{array}$ & $\begin{array}{l}2003 / 2004 \\
2017 \text { (acc) }\end{array}$ & $\mathrm{NE}$ & $140-200$ \\
\hline $\begin{array}{l}\text { Basin Creek } \\
\text { 1995: State Forest } \\
\text { (production) } \\
\text { 2018: Future } \\
\text { Potential Production } \\
\text { Forest }\end{array}$ & - & 41 & $\begin{array}{l}\text { north of Loila Tier Road } \\
\text { above Basin Creek }\end{array}$ & ridge & 05/2012 (frb) & $\mathrm{N}, \mathrm{NE}$ & $350-360$ \\
\hline
\end{tabular}




\section{APPENDIX 5}

\section{Hibbertia calycina height and fire}

The assumption of homogeneity of variances for mean plant height per sub-population using 2017/2018 data only was examined using Levenes test and the difference between the mean heights of plants for each of ten clumps was tested using Welch's One-way Analysis of Variance (ANOVA). Rather than minimum and maximum, we used 95\% confidence intervals to remove the influence of outliers (Walshe et al. 2007) except where otherwise indicated and standard error is used. Analyses were performed using R (package agricolae version 1.3-0, de Mendiburu 2019; package userfriendlyscience version 0.7.2, Peters (2018); R Core Team (2019)).

Mean plant height $( \pm 95 \%$ confidence interval) recorded from a random subset of clumps during the 2017/2018 survey. See table 1 for clump data. One-way ANOVA was used to compare mean plant height and Tukey's test used to denote different means (denoted by letters A-G). All plants: $F=28.27(\mathrm{df}=9), \mathrm{p}<0.0001$; F (Welch's ANOVA) $=52.04(\mathrm{df}=9), \mathrm{p}<0.0001$.

\begin{tabular}{|c|c|c|c|c|c|c|c|c|c|c|c|}
\hline Variable & $\begin{array}{c}\text { Skyline } \\
35\end{array}$ & $\begin{array}{c}\text { Mt } \\
\text { Echo2 }\end{array}$ & $\begin{array}{c}\text { Mt } \\
\text { Echo3 }\end{array}$ & $\begin{array}{c}\text { Loila } \\
\text { Pinnacle/ } \\
\text { Wolfram } \\
\text { 6-8 }\end{array}$ & $\begin{array}{c}\text { Loila } \\
\text { Pinnacle/ } \\
\text { Wolfram } \\
10 \\
\end{array}$ & $\begin{array}{c}\text { Loila } \\
\text { Pinnacle/ } \\
\text { Wolfram } \\
15-17\end{array}$ & $\begin{array}{c}\text { Pyramid } \\
23-29\end{array}$ & $\begin{array}{c}\text { Pyramid } \\
30\end{array}$ & $\begin{array}{c}\text { Oreico } \\
31\end{array}$ & $\begin{array}{c}\text { Skyline } \\
35\end{array}$ & $\begin{array}{c}\text { McIntyres } \\
37\end{array}$ \\
\hline $\begin{array}{l}\text { Number of } \\
\text { individuals }\end{array}$ & 186 & 299 & 252 & 160 & 75 & 137 & 148 & 103 & 126 & 186 & 182 \\
\hline $\begin{array}{l}\text { Mean } \\
\text { height } \\
(\mathrm{cm}) \pm \mathrm{se}\end{array}$ & $\begin{array}{l}16.32 \mathrm{~F} \\
\pm 2.85\end{array}$ & $\begin{array}{c}28.46 \mathrm{DE} \\
\pm 2.50\end{array}$ & $\begin{array}{c}24.83 \mathrm{E} \\
\pm 1.79\end{array}$ & $\begin{array}{c}33.39 \mathrm{CD} \\
\pm 3.07\end{array}$ & $\begin{array}{c}29.51 \mathrm{CDE} \\
\pm 4.04\end{array}$ & $\begin{array}{c}31.77 \mathrm{CD} \\
\pm 3.34\end{array}$ & $\begin{array}{c}41.02 \mathrm{AB} \\
\pm 3.02\end{array}$ & $\begin{array}{l}43.37 \mathrm{~A} \\
\pm 4.19\end{array}$ & $\begin{array}{c}32.10 \mathrm{CD} \\
\pm 3.34\end{array}$ & $\begin{array}{l}16.32 \mathrm{~F} \\
\pm 2.85\end{array}$ & $\begin{array}{c}35.08 \mathrm{BC} \\
\pm 2.85\end{array}$ \\
\hline $\begin{array}{l}\text { Minimum } \\
\text { height } \\
(\mathrm{cm})\end{array}$ & 1 & 2 & 2 & 2 & 2 & 1 & 5 & 4 & 2 & 1 & 4 \\
\hline $\begin{array}{l}\text { Maximum } \\
\text { height } \\
(\mathrm{cm})\end{array}$ & 54 & 120 & 70 & 82 & 83 & 81 & 99 & 133 & 76 & 54 & 134 \\
\hline
\end{tabular}

There was a difference in clump mean plant height $(\mathrm{F}=28.27 \mathrm{df}=9, \mathrm{p}<0.0001)$. Pairwise comparisons found the mean plant height from Skyline35 was significantly different from all other clumps where height was recorded. Pyramid30 recorded the greatest mean plant height (mean $=43.37 \pm 2.11 \mathrm{~cm}$ ), similar only to nearby Pyramid 23-29 clumps). Time since the most recent fire appears to not influence the mean height of $H$. calycina plants (appendix 3). Pyramid30 and McIntyres37 ridgeline clumps recorded the high mean height of plants and longest time since fire. A clump from Skyline recorded the same time since fire and lowest mean height of plants.

\section{References}

de Mendiburu, F. 2019: agricolae: Statistical Procedures for Agricultural Research. R package version 1.3-0. https://CRAN.R-project. org/package=agricolae.

Peters, G. 2018: userfriendlyscience: Quantitative analysis made accessible_. doi: 10.17605/osf.io/txequ (https://doi.org/10.17605/osf. io/txequ), R package version 0.7.2, (https://userfriendlyscience.com).

R Core Team 2019: R: A language and environment for statistical computing. R Foundation for Statistical Computing, Vienna, Austria. www.R-project.org/.

Walshe, T., Wintle, B., Fidler, F. \& Burgman, M. 2007: Use of confidence intervals to demonstrate performance against forest management standards. Forest Ecology \& Management 247: 237-245. 